
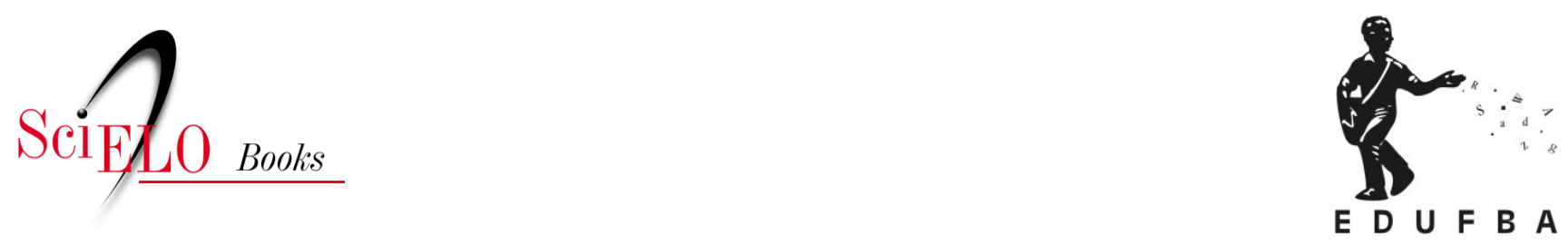

\title{
O movimento
}

\author{
Luciana Xavier de Oliveira
}

\section{SciELO Books / SciELO Livros / SciELO Libros}

OLIVEIRA, L. X. O movimento. In: A cena musical da Black Rio: estilos e mediações nos bailes soul dos anos 1970 [online]. Salvador: EDUFBA, 2018, pp. 73-157. ISBN: 978-85-232-1872-0.

https://doi.org/10.7476/9788523218720.0004.

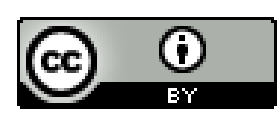

All the contents of this work, except where otherwise noted, is licensed under a Creative Commons Attribution 4.0 International license.

Todo o conteúdo deste trabalho, exceto quando houver ressalva, é publicado sob a licença Creative Commons Atribição 4.0.

Todo el contenido de esta obra, excepto donde se indique lo contrario, está bajo licencia de la licencia Creative Commons Reconocimento 4.0. 


\section{O movimento}

A quase totalidade dos textos jornalísticos, trabalhos acadêmicos e depoimentos públicos que abordam a memória do chamado movimento Black Rio se apoia na tônica da temática da busca, construção e afirmação de uma identidade específica, influenciada por uma cultura internacional. Uma identidade negra que se oporia fortemente à retórica do mito da democracia racial, como aponta McCann (2002), e cuja discursividade residiria sobre uma ideologia de resistência, altamente influenciada pelas proposições de alguns movimentos negros norte-americanos.

Não raramente, é possível observar o modo como diferentes autores de áreas diversas articulam as suas investigações na abordagem do fenômeno, que gira em torno da constituição dos bailes black como espaços de novas constituições identitárias afro-brasileiras. Nesse conjunto de textos acadêmicos "clássicos" que abordam a história do movimento Black Rio, perpassa-se a ideia de que o negro brasileiro, enquanto elemento étnico, para além do fenótipo, estaria em busca de uma identidade - não necessariamente considerada autônoma e autêntica - por intermédio de um processo de conscientização racial e combate ao racismo. Alguns autores ainda identificam a necessidade da constituição de uma produção cultural específica e legítima diante da apropriação pelo Estado do samba, do Carnaval ou de religiões de matriz 
africana na formatação de uma identidade nacional razoavelmente homogênea, apesar de conflituosa, retirando ou diluindo possíveis traços "negros" dessas manifestações. Assim, o também chamado movimento Black Soul seria uma resposta e reação a um suposto "assalto cultural" cometido pelo Estado e pelas elites brasileiras, permeado por influências de uma cultura global em consonância com a evolução dos meios de comunicação massivos. Seus principais participantes, portanto, acabaram por beber de fontes internacionais, notadamente da cultura negra norte-americana, como maneira de suprir uma "carência identitária".

Faz-se necessário mencionar que esses textos acadêmicos não se voltam exclusivamente para o estudo e análise do movimento Black no contexto brasileiro, mas abordam outras manifestações culturais das quais essa cena musical seria uma corrente convergente, uma etapa paralela a um processo mais amplo, ora em relação à própria formação do movimento negro brasileiro, ora como um momento embrionário de desenvolvimento de gêneros musicais como o funk carioca, o rap paulistano e o samba-reggae baiano, de certa forma, assumindo um lugar de dado contextual e aspecto coadjuvante. Poucos foram os trabalhos encontrados que tiveram o movimento soul como objeto central no conjunto das reflexões. A busca por referências, no entanto, revelou que, apesar da pouca atenção dada pela academia a esse objeto, alguns pesquisadores produziram reflexões preliminares à época do fenômeno ou em um momento imediatamente posterior, sempre articulando o Black Soul - em outras cidades do Brasil - à reorganização do movimento negro brasileiro e de uma consciência étnica em diferentes regiões do país na década de 1970.

Para Domingues (2007), o movimento negro no Brasil precisa ser definido de forma plural, englobando mobilizações de populações afrodescendentes em torno da resolução de questões sociais provenientes do racismo, da segregação e da marginalização na sociedade. Esses grupos instrumentavam a raça e a identidade étnico-racial em suas acepções simbólicas para mediar reivindicações políticas e articular a organização dos negros ao redor de projetos comuns de ação. Desse modo, os movimentos negros podem dizer respeito a entidades de qualquer natureza, como culturais, religiosas - terreiros de candomblé, por exemplo-, assistenciais, recreativas, artísticas - grupos de 
dança, teatro, capoeira - e culturais, como os centros de pesquisa e Organizações Não Governamentais (ONGs). Em termos políticos, desde o período pós-abolição, libertos, ex-escravos e descendentes criaram algumas entidades de mobilização racial, como grêmios e clubes em vários estados, como o Clube 13 de Maio dos Homens Pretos, em São Paulo em 1902, o Centro da Federação dos Homens de Cor, no Rio de Janeiro, enquanto no Rio Grande do Sul já havia sido criada a Sociedade Progresso da Raça Africana, em 1891. Essas associações negras tinham um mote assistencialista, recreativo e cultural e, por vezes, eram organizadas por classes de trabalhadores como portuários e ferroviários. Na mesma época, surgiam as primeiras manifestações de uma imprensa negra alternativa, cujos jornais eram voltados para a discussão de questões raciais e cujos títulos mais famosos eram produzidos em São Paulo. "Nesta etapa, o movimento negro organizado era desprovido de caráter explicitamente político, com um programa definido e projeto ideológico mais amplo”. (DOMINGUES, 2007, p. 105) Havia uma afirmação de viés mais cultural, de acordo com Pires (2015, p. 27), desde os anos 1930, a partir de um processo de articulação cultural que se opunha ao ideal de democracia racial estabelecido como uma espécie de "pacto político de contenção de massas”, que alocava práticas culturais de origem africana em uma posição subordinada a partir do caráter sincrético da contribuição dos negros à cultura nacional.

Nessa mesma década, foi fundada em São Paulo a Frente Negra Brasileira (FNB), uma das primeiras organizações negras deliberadamente políticas, com atuação em nível nacional, chegando a contar com mais de 20 mil associados. A FNB foi convertida em partido político, mas logo foi extinta em 1937, durante a ditadura do Estado Novo. Entre os anos 1940 e 1960, outras entidades foram criadas, além dos jornais da imprensa negra, mas sem a mesma força e amplitude e, apesar de alguns dirigentes terem sido eleitos para cargos públicos, mantiveram-se isolados politicamente. A exceção foi o Teatro Experimental do Negro (TEN), criado no Rio de Janeiro em 1944 e liderado por Abdias do Nascimento. ${ }^{1} \mathrm{O}$ TEN foi inspirado pela ideologia

1 Abdias do Nascimento (1914-2011) foi um dos maiores expoentes da cultura afro-brasileira, poeta, ator, escritor, dramaturgo, artista plástico, professor universitário, político e ativista dos 
da négritude, de Aimé Césaire e Léopold Senghor, e possuía grande vitalidade, desenvolvendo uma série de ações em defesa dos direitos civis da população negra, propondo a criação de leis antirracistas no Brasil. ${ }^{2}$ Como outras organizações negras, também foi desmobilizado durante a ditadura, sendo extinto em 1968 por ocasião do autoexílio de Abdias do Nascimento nos EUA. O governo militar também esvaziou outros movimentos que passaram para a semiclandestinidade, e só na década de 1970 que organizações civis e populares passaram a se reorganizar, incluindo a imprensa negra e o Grupo Palmares, de Porto Alegre (1971). No Rio de Janeiro, foi criado o Centro de Estudos Afro-Asiáticos (Ceaa) em 1973, a Sociedade de Intercâmbio Brasil-África (Sinba) em 1974, o Instituto de Pesquisas das Culturas Negras (IPCN) em 1975, mesmo ano de criação do Grupo de Trabalho André Rebouças e do Centro de Estudos Brasil-África (Ceba). Três anos depois, foi criado um grupo organizado político efetivamente, o Movimento Negro Unificado (MNU), entidade com uma pauta concreta de enfrentamento ao regime militar, de orientação majoritariamente marxista-socialista. ${ }^{3} \mathrm{E}$ tanto o IPCN quanto o MNU tinham uma ligação com a realização dos bailes soul no Rio e São Paulo, respectivamente, e era nas festas que muitas lideranças arregimentavam novos militantes.

Uma das primeiras reflexões acadêmicas sobre a ligação entre os bailes e a ação militante de negros foi apresentada em 1980, por Carlos Benedito Rodrigues da Silva, no IV Encontro da Associação Nacional de Pós-Graduação

direitos das populações negras. Atuou em movimentos nacionais e internacionais, como a FNB, a Négritude e o Pan-Africanismo, e foi fundador de entidades como o Museu da Arte Negra (MAN) e o Instituto de Pesquisas e Estudos Afro-Brasileiros (Ipeafro), além de ter sido posteriormente um dos idealizadores do MNU.

2 "A proposta original era formar um grupo teatral constituído apenas por atores negros, mas progressivamente o TEN adquiriu um caráter mais amplo: publicou o jornal Quilombo, passou a oferecer curso de alfabetização, de corte e costura; fundou o Instituto Nacional do Negro, o Museu do Negro; organizou o I Congresso do Negro Brasileiro; promoveu a eleição da Rainha da Mulata e da Boneca de Pixe; tempo depois, realizou o concurso de artes plásticas que teve como tema Cristo Negro, com repercussão na opinião pública”. (DOMINGUES, 2007, p. 109)

3 Essa não era necessariamente uma postura unânime da entidade, e havia divergências político-partidárias entre seus membros. Para um aprofundamento a respeito da história do movimento negro no Brasil, ver: Hanchard (2001) e Alberto (2011). 
e Pesquisa em Ciências Sociais (Anpocs), no grupo de trabalho "Temas e problemas da população negra no Brasil". O trabalho pioneiro intitulado "Black Soul: aglutinação espontânea ou identidade étnica” é uma análise do movimento Black deflagrado em São Paulo. Nele, o autor apontava a existência de modernas formas globalizadas de produções culturais negras para além daquelas de origem africana. Silva (1980) propunha uma análise do grupo Afro-Soul, sediado em Campinas e criado em 1978 por jovens negros interessados na realização de bailes de soul para um público também negro que não tinha acesso às festas e eventos de lazer promovidos em clubes tradicionais da cidade. $\mathrm{O}$ autor estava interessado em compreender se essa equipe de soul, enquanto representante de uma cena musical maior, tinha uma motivação mais voltada para os negócios e para o entretenimento, ou se haveria uma "[...] proposta mais concreta de conscientização do negro em busca de sua identidade étnica”. (SILVA, 1980, p. 2) Silva (1980, p. 2) partia do pressuposto de que o grupo Afro-Soul seria um exemplo de uma forma contemporânea de aglutinação étnica que tinha um "caráter de mobilização de elementos negros através da música” e também por outros elementos como roupas e danças, que emulavam uma forma de organização importante no processo de formação da consciência do negro em Campinas e, por extrapolação, em outras cidades onde ocorria fenômeno semelhante.

Para isso, o autor se atém a uma implicação local das atividades do grupo, mas sinaliza um dado interessante que pode ser incorporado em outras análises sobre a cena black no Brasil: a constituição de um conjunto de ações culturais promovidas por uma ainda insurgente classe média, ou mesmo de uma "elite" negra, que se configurava em alguns centros urbanos. "São pessoas que se pode dizer que conseguiram furar o bloqueio, tiveram acesso a um tipo de educação que a maioria da população negra não tem, e isso lhes atribui uma certa importância no meio negro”. (SILVA, 1980, p. 5) Além de um maior nível escolar, o autor aponta para uma articulação entre os principais integrantes da equipe com outros indivíduos e instituições socioculturais negras locais como associações beneficentes, grupos de teatro, órgãos de imprensa negra. Como apresentarei com mais profundidade no capítulo "Blacks sob vigilância”, apesar de uma grande maioria da população negra ainda permanecer no subproletariado urbano, após 1930, percebeu-se a emergência 
de uma pequena classe média formada por não brancos e a crescente incorporação de uma quantidade substancial de negros e afro-mestiços à classe trabalhadora industrial, que experimentou mais ganhos econômicos e sociais com relação às gerações passadas. Naquele momento, o sociólogo Hasenbalg (1979, p. 249) observava:

Contudo, devido a suas realizações educacionais mais elevadas e às formas de discriminação encaradas em seu movimento ascendente, este grupo está em melhor posição para visualizar a operação de mecanismos racistas. Com base nisto, é possível conceber este grupo como a principal fonte de liderança negra, tendo, de fato, as raras manifestações de não-conformismo racial durante as últimas décadas partido dos membros mais jovens e educados da classe média de cor.

Mesmo assim, para Silva (1980), como para outros autores, a preocupação das equipes de soul com o lazer seria maior que uma visão e uma proposta concreta de um movimento racial. $\mathrm{O}$ autor também considerava que a preocupação com a busca e a demonstração pública de um certo status alcançado por meio da integração em uma sociedade de consumo superaria possíveis interesses políticos: "Curiosamente, parece que os grupos acabam incorporando os padrões estabelecidos pela sociedade dominante, procurando serem reconhecidos como negros bem sucedidos”. (SILVA, 1980, p. 7) Esse desejo, para Silva (1980), também estaria representado no processo de ocupação de espaços anteriormente negados, como clubes frequentados apenas pela elite branca local, nos quais era vedada a entrada de negros. ${ }^{4}$ Essas inter-

4 "Mas, é preciso ver o que significa dar uma festa no Tênis Club, que e um dos mais conhecidos clubes da elite branca da cidade. Ainda que se utilize somente as quadras de esporte, essa situação aponta para a questão racial, na medida em que não estariam entrando no clube como um grupo qualquer, mas como um grupo de negros. Também significa ocupar um espaço que normalmente não lhe é permitido". (SILVA, 1980, p. 6) A situação da interdição da entrada de negros em espaços "brancos" da elite e da classe média de Campinas, conforme descrição em outras passagens do artigo de Silva, também era articulada à questão da classe social, como denuncia Assef (2003, p. 21) em relação ao contexto de São Paulo: "Ao contrário de países como os Estados Unidos, não havia no Brasil um código social que vetasse a entrada de negros nesses bailes. O fator excludente era mesmo o alto preço dos ingressos". 
dições parecem ter sido frequentes também no Rio de Janeiro, como lembra Oziléia Souza: "Na época, aqui em Volta Redonda, tinha um clube em que não podiam entrar negros, Clube dos Funcionários, e eu ficava indignada com isso". Em diversas passagens de seu artigo sobre a Black Rio, Lena Frias ilustra a questão ao transcrever o depoimento de um jovem negro de 17 anos, auxiliar de escritório:

O problema é o seguinte: em Mesquita tem dois clubes, o Mesquita Futebol Clube, que é da gente, e o Mesquita Tênis Clube, em que não entra preto. Eu fui querer entrar num baile no Tênis Clube, em janeiro, e não deixaram. Era um baile de conjunto. Eles disseram que a gente não podia entrar, criava tumulto. É por isso que nos bailes Black não tem White. (FRIAS, 1976, p. 5)

Havia, por esses jovens negros produtores e frequentadores, um maior cuidado com a apresentação, enfatizando um "bom comportamento", a criação de uma atmosfera não violenta de qualquer ordem, a respeitabilidade, imagens distantes das atribuições estereotipadas tipicamente relacionadas ao elemento negro. Esse desejo de transmitir uma imagem diferenciada também residia na questão da aparência, como forma de garantir o seu reconhecimento como "negros de bem". (SILVA, 1980, p. 12) Mesmo assim, para o autor, esses dados não apagariam o sentido de mobilização presente nesses eventos festivos: "[...] o fato dessas pessoas serem negras em sua maioria, e estarem reunidas em um mesmo lugar, ainda que por algumas horas, pode ter um sentido de resistência, e um significado importante para a conscientização do negro". (SILVA, 1980, p. 13)

Apesar de não avançar muito mais nas reflexões a respeito da importância dessa cena Black Soul e em suas implicações político-culturais, Carlos Silva levanta algumas questões pertinentes como o motivo da escolha da música norte-americana como amálgama de uma "aglutinação étnica" dos negros brasileiros. Uma das possíveis razões, um tanto holística, era de que o soul,

5 Babá e frequentadora dos bailes. Entrevista concedida à autora por telefone, Rio de Janeiro, 26 abr. 2016. 
em relação ao samba e a outros gêneros musicais afro-brasileiros, representava uma música que possuiria uma "força interior maior", explanação que deixo de lado neste momento por uma falta de sustentação teórica. Mas me atenho a uma outra justificativa dada por Silva (1980): a de que a black music, em geral, simbolizaria uma possibilidade de "ascensão social”, representada pelas imagens de seus principais artistas, que ultrapassava fronteiras nacionais e chegava a uma população marginalizada. O soul era a trilha sonora da luta contra o sistema racista presente na sociedade norte-americana, compreendido pelos adeptos da democracia racial como mais severo e mais grave que o racismo brasileiro. Naquele momento de maior conscientização e mobilização entre as populações negras brasileiras, esse gênero musical pareceria, pois, mais adequado a um acirramento das discussões em relação ao preconceito racial - ao menos, mais pertinente do que o samba, já apropriado pelas elites e outras camadas da população, o que teria levado ao seu "embranquecimento".

A respeito do conceito de democracia racial brasileira, Abdias do Nascimento (1978, p. 41) já denunciava a irrealidade contida na máxima de que negros e brancos conviveriam "harmoniosamente, desfrutando iguais oportunidades de existência sem nenhuma interferência, nesse jogo de paridade social, das respectivas origens raciais ou étnicas”. Para o autor, esse argumento ocultaria um racismo característico do Brasil, eficazmente institucionalizado nas estruturas mais profundas da sociedade e "difuso no tecido social, psicológico, econômico, político e cultural da sociedade do país”. (NASCIMENTO, 1978, p. 93) Domingues (2005, p. 2) argumenta que a democracia racial, "a rigor, significa um sistema racial desprovido de qualquer barreira legal ou institucional para a igualdade racial, e, em certa medida, um sistema racial desprovido de qualquer manifestação de preconceito ou discriminação”. Ela se configura como mito de acordo com o que Barthes (2009) propõe, pois o mito é um sistema de comunicação que transmite uma mensagem, um modo de significação originário de um contexto histórico e de condições de funcionamento a partir de constantes reinvestimentos da sociedade. Assim, o mito não necessariamente é uma verdade ou uma mentira: ele é um discurso que não se define pelo objeto da sua mensagem, mas pela maneira como essa mensagem é proferida e devidamente apropriada pela sociedade. E, como define Barthes (2009), "é a História que transforma o real em discurso". 
O mito se reporta a um processo contextualizado historicamente a partir de uma representação social formada mediante uma matéria já trabalhada, a fim de garantir a comunicação apropriada de uma determinada ideologia. Para Ortiz (2006, p. 38), o conceito de mito ainda sugere um ponto de origem a partir do qual se irradia uma história e um discurso mítico: "Sabemos em Antropologia que os mitos tendem a se apresentar como eternos, imutáveis, o que de uma certa forma se adequa ao tipo de sociedade em que são produzidos". Portanto, a ideia de uma democracia racial se configurar como mito diz respeito ao fato dessa visão estar consolidada no imaginário coletivo social do Brasil, transformada em ideologia oficial das relações raciais no contexto nacional, cujo ideário possui determinadas raízes históricas que remontam ao século XIX, como afirma Domingues (2005). Essa ideologia está intrinsecamente enraizada na produção intelectual de uma elite acadêmica e política interessada em transferir para os negros o peso por sua condição desprivilegiada na sociedade, o que incentivou e exaltou o processo de mestiçagem tanto como forma de "branqueamento" da população, como também celebrado como um sinal da inexistência de barreiras raciais. Mas Domingues (2005) também não exclui a responsabilidade do movimento abolicionista institucionalizado - representado pela figura de Joaquim Nabuco e da imprensa negra do começo do século -, que endossou essa ideologia, frequentemente comparando o sistema racial brasileiro ao norte-americano, representado pelo código oficial segregacionista sulista das Leis de Jim Crow, ${ }^{6} \mathrm{e}$ ao sul-africano (o apartheid), ${ }^{7}$ reconhecendo o Brasil como um modelo mais brando e até mesmo um paraíso multirracial: "Ao negar o preconceito racial, contribuía-se para desarticular a luta política antirracista, pois não se combate o que não existe”. (DOMINGUES, 2005, p. 8) O contexto da democracia

6 As Leis de Jim Crow se referem a uma legislação estadual decretada nos estados sulistas e limítrofes dos EUA que vigorou entre 1876 e 1965, cujas premissas mais contundentes exigiam que as escolas públicas e a maioria dos locais públicos (incluindo transportes) tivessem instalações separadas para brancos e negros. Esse conjunto de leis também afetava asiáticos e outros grupos minoritários.

7 A política oficial do apartheid (que significava "separação") foi adotada entre 1948 a 1994 na África do Sul, baseada no cerceamento dos direitos da maioria dos habitantes negros e instituída por governos sucessivos formados por uma minoria branca, que estabeleceram um regime de segregação racial. 
racial, de acordo com Fry (1996, p. 127), possibilitava uma hierarquização dos corpos de acordo com sua gradação de cor e não seria menos "real" que a discriminação "racial”, baseada na hierarquização de corpos de acordo com a raça.

Também o próprio movimento comunista brasileiro auxiliou na consolidação desse mito, pois, para esse grupo, o racismo era produzido pela diferença de classes, em que a injustiça racial era entendida como resultado das diferenças de ordem econômica e social. Mas o mito é ambíguo, pois existem dificuldades concretas e condições materiais racistas que impedem a sua total realização e, assim, a sua existência é puramente simbólica, pois se realiza no âmbito da linguagem. Mas, ao ser reelaborada e acionada social e coletivamente de forma sucessiva ao longo do tempo nas relações do cotidiano ou em discursos oficiais e midiáticos, a ideologia da democracia racial apresenta barreiras concretas para o desenvolvimento de ações políticas negras em um contexto social marcado pelo discurso da brasilidade mestiça. Por isso, para Ortiz (2006, p. 44), já que os próprios negros também se definem como brasileiros, o mito das três raças se torna exemplar e problemático, pois ele não apenas encobre tensões raciais como faz com que todos se reconheçam como nacionais.

Se Silva (1980) considerava importantes as reuniões públicas em bailes e eventos festivos de grupos negros como atos mobilizadores e conscientizadores, ele descartava o potencial político presente no consumo, entendido como mera tentativa de ingresso na sociedade capitalista, mesmo que fundamentasse uma identidade contraditória “como cidadãos". De certa forma, Silva (1980, p. 20) adiantava uma reflexão mais contemporânea em relação ao consumo como uma possibilidade de aquisição de uma cidadania alternativa e da construção de novos exercícios identitários "negros". Essa não parece ser a mesma visão de Lauro Cavalcanti, antropólogo, no artigo "Black-Breque: Estudo de um grupo ‘soul' em relação a adeptos do samba” (1981), também apresentado no encontro anual (Anpocs) realizado ano seguinte, no mesmo GT em que Carlos Silva apresentou seu artigo.

Hoje, vemos que esse texto representa um avanço nas reflexões sobre o movimento black brasileiro, e Cavalcanti (1981) enfocou especificamente o contexto carioca para promover um debate e uma comparação com o samba da época. A reflexão sobre esses embates e tensões foi utilizada para 
compreender a maneira pela qual esses dois gêneros - o samba e o soul - processariam identidades e etnicidades distintas a partir da confrontação de discursos de informantes oriundos desses dois universos. Cavalcanti (1981) tenta localizar o fenômeno do Black Soul dentro de um contexto mais amplo de emergência de movimentos de minorias étnicas em todo mundo, desencadeados especificamente no pós-guerra. Esse cenário chamou a atenção para a importância da etnicidade como fator preponderante de demarcação de diferenças e de novos significados a partir da configuração de categorias sociais distintas para além da classe. $\mathrm{O}$ autor apontou como exemplo significativo dessa nova compreensão do mundo moderno o crescimento do debate a respeito da questão racial, elencando algumas questões principais que mobilizavam o ainda insurgente movimento negro brasileiro:

A década de 70 no Brasil presenciou o debate da situação de negro em nossa sociedade de maneira tão intensa como jamais ocorrera anteriormente. Inúmeros grupos de intelectuais negros se reuniram e começaram a discutir sua identidade étnica, estudar seu passado e reivindicar seus direitos no presente. Houve a preocupação de auto-definição do grupo como afro-brasileiro, categoria que não estava tão impregnada pelo estigma do preconceito como crioulo, preto e negro; foi difundido, também, um questionamento da 'estética da brancura', que elegia os traços físicos tipicamente arianos como os mais belos, passando-se a tirar partido de características especificamente negras, como o cabelo encarapinhado, anteriormente rejeitado e disfarçado pelo alisamento. (CAVALCANTI, 1981, p. 2)

Cavalcanti aproveitou ainda para enumerar algumas críticas feitas aos participantes dos bailes black - que serão abordadas com mais profundidade no capítulo "O movimento" -, que consistiam em, por um lado, considerar o soul como resultado de uma importação de uma tendência cultural americana que não se encaixaria na realidade brasileira, especialmente segundo a visão de adeptos da democracia racial; enquanto outra visão criticava o movimento por uma suposta alienação, considerando o problema das classes sociais superior à questão racial. Iniciativas de mobilização político-racial, em geral, enfrentavam reações teóricas no Brasil, principalmente seguindo duas 
tendências. Uma mobilizava-se em defesa da democracia racial brasileira, que enaltecia a miscigenação e negava o racismo, em um país tido como "paraíso racial”, considerando qualquer movimento negro artificial e alienígena à realidade nacional. Para esse pensamento, tendências mais radicais de mobilização negra poderiam levar a conflitos. Uma segunda vertente de pensamento admitia, efetivamente, a existência do preconceito, mas atribuído à questão das classes sociais, pouco enfatizando a questão especificamente racial:

supõe essa linha de pensamento que o negro cessará de ser discriminado quando for resolvida a situação de disparidade das classes sociais, não vendo necessidade, portanto, de atribuir maior importância a um movimento negro que enfatize a questão étnica. (CAVALCANTI, 1981, p. 3)

Cavalcanti (1981, p. 3), nesse caso, busca uma terceira posição, ao tentar atribuir um significado maior ao soul, que, segundo ele, se constituiria, na época, talvez como "o único evento especificamente negro que mobilize grande número de pessoas”. Isso justificaria, para o autor, a sua comparação ao samba e a sambistas negros enquanto "exemplo máximo de negritude e brasilidade”, com discursos identitários e visões comuns entre os dois segmentos, mesmo que houvesse cisões e disputas.

Também é de 1981 o livro Carnaval Ijexá, de Antônio Risério. A obra, que teve apenas uma edição, é um testemunho situado entre o acadêmico, a crônica e a poesia sobre o desenrolar das novas ações e produções culturais afro-baianas durante os anos 1970, superpostas àquilo que o autor chama de "reafricanização", ${ }^{8}$ processo catalisador da influência negra norte-americana na configuração de um contexto "afro-ijexá", que incorporava convergentemente questões culturais derivadas dos processos de libertação das antigas colônias portuguesas na África e traços da tradição afro-brasileira. Essa reafricanização seria marcada pelo uso, no cotidiano ou no contexto da festa, de símbolos ligados a uma determinada africanidade que demarcavam uma

8 Uma definição espontânea de reafricanização, para Risério (1981, p. 13): “Os pretos se tornam mais pretos, digamos assim; se interessam cada vez mais pelas coisas da África e da negritude. Mas vivem, intensa e essencialmente, o presente, jogando aberto para o futuro". 
interação tanto com uma ancestralidade e uma mitologia quanto com uma cultura globalizada, em fluxos desiguais e desterritorializados de símbolos mundiais diaspóricos. Discutindo diversos temas, Risério analisa as dinâmicas internas da vida da juventude afro-mestiça baiana, especialmente no tocante às atividades de entidades carnavalescas recém-criadas, como os blocos afro e afoxés, bem como as relações dessas agremiações com o movimento negro na Bahia e, por conseguinte, no Brasil, realçando a importância da politização do carnaval, do corpo e da música.

Para Risério (1981, p. 18), esses processos coexistentes e paralelos da reafricanização estariam se desenvolvendo no interior de um "boom da negritude" e teriam sua direta expressão tanto nas performatizações públicas de uma cultura até então restrita a "guetos" e espaços periféricos, como na própria expansão física, social e cultural da periferia até locais públicos da cidade. Como exemplo, o autor reproduz a frase do ator baiano Mário Gusmão (1928-1996), primeiro negro formado na Faculdade de Teatro da Universidade Federal da Bahia (UFBA): "O Ilê foi, simplesmente, o bloco que teve a coragem de botar no meio da rua aquilo que antes só acontecia na cozinha”. (RISÉRIO, 1981, p. 18) No mesmo trecho, Gilberto Gil, em entrevista ao autor, considera o momento como aquele em que "os negros começam a conquistar a possibilidade de se autogerir esteticamente”. (RISÉRIO, 1981, p. 18) Assim, o autor aponta para as potencialidades de uma maior autonomia por meio da estética, empreendidas por um determinado grupo de jovens afro-mestiços baianos, que utilizavam a festa, a música, a dança, o corpo e a performance como substratos para uma possibilidade concreta de transformação social.

9 Ao longo do livro, Risério utiliza diversas vezes o termo "gueto" para se referir aos bairros periféricos pobres e negros de Salvador, utilizando o termo de acordo com o senso comum. No entanto, diante da observação da sociedade brasileira ao longo de sua história, a associação de gueto à experiência racial brasileira aparece um tanto deslocada, pois, de acordo com Wacquant (2004), o conceito de gueto se refere a uma historiografia ligada à diáspora judaica pela Europa e se relaciona ainda à experiência negra nas grandes cidades norte-americanas. A "guetização", que tinha um propósito definido de cercamento e controle étnico-racial, era um dispositivo sócio-organizador segregador do espaço urbano pautado por uma violência coletiva, com propósitos de ostracismo social. Wacquant considera as áreas pobres brasileiras como exemplos de aglomerações étnicas, marcadas pela pobreza e segregação, mas guardando suas especificidades. 
Algumas passagens do livro de Risério foram retomadas por Vianna em 1988, na publicação mais famosa e pioneira sobre o funk no Rio de Janeiro, O mundo funk carioca. O livro de Vianna representou um marco para os estudos acadêmicos sobre o funk e foi derivado de sua dissertação de mestrado em Antropologia (1987). Nele, Vianna descortinou uma cena musical e um universo que até então eram ignorados pela grande mídia e pela classe média brasileira. Ao tentar traçar uma genealogia do funk carioca, originado tanto do funk norte-americano das décadas de 1960 e 1970 quanto das batidas eletrônicas do freestyle e do Miami bass, ${ }^{10}$ Vianna abordou a história da Black Rio e de sua metamorfose no movimento do charme nos anos 1980, analisando a ligação concreta entre o universo cultural do funk e a vida nas favelas do Rio de Janeiro em seu cotidiano de exclusão social. Mas deixa de lado a problemática racial, o que pode estar relacionado a uma dificuldade de identificar esses fatores na produção de desigualdade e identidade, como critica Pinho (2005, p. 134).

Outro trabalho seminal sobre o universo do funk e também do rap no Rio de Janeiro foi o livro de Micael Herschmann, O funk e o hip hop invadem a cena (2000). O foco do trabalho de Herschmann (2000, p. 19) recai sobre o debate sociocultural e sobre as transformações na cidade, enfocando as narrativas sobre violência e cultura urbana que giravam em torno das figuras de funkeiros e rappers, a fim de refletir sobre o lugar do pobre no debate político e intelectual brasileiro. Para isso, Herschmann recorreu aos primórdios do movimento soul, mapeando as condições de emergência do funk e do hip hop no Rio de Janeiro e abordando as diferentes estratégias que esses jovens utilizavam para se inserir na cena cultural pública. $\mathrm{O}$ autor parte da música e dos bailes para compreender a criação de novos patamares e modelos de cidadania, próximos da comunicação de massa e do consumo (HERSCHMANN,

10 Freestyle é um gênero musical originado na virada dos anos 1970 para os 1980, diante da decadência da disco music, basicamente desenvolvido em comunidades latinas e negras de Nova York e Miami. Utilizando batidas eletrônicas de teclados e sintetizadores e misturando elementos rítmicos e melódicos do R\&B, dance e house music, era uma música dançante, mas melódica, com temática romântica, que, por sua vez, deu origem ao Miami bass, mais dançante e sincopado, com batida mais grave e intensa, fundamentado sobre a atuação criativa de DJs, substituindo temas românticos pela fala das ruas em gravações com temáticas sexuais, que baseou a constituição do funk carioca. 
2000, p. 38-39), analisando como essas práticas culturais, representações e estilos de vida refletiam a realidade e as dinâmicas sociais.

Alguns estudos acadêmicos sobre a história do movimento negro no Brasil foram produzidos tanto por pesquisadores brasileiros quanto estrangeiros, e dentre eles, destaca-se o livro de Michael Hanchard, Orfeu e o poder, o movimento negro no Rio de Janeiro e São Paulo (1945-1988), publicado no Brasil em 2001, traduzido do original em inglês lançado em 1994. Resultado de sua tese de doutorado em Ciência Política da Universidade de Princeton, em Nova Jersey, Hanchard se propôs a compreender a constituição do movimento negro no Brasil, partindo das cidades de São Paulo e Rio de Janeiro. Para o autor, as organizações políticas afro-brasileiras não possuíram um percurso sistemático e constante em comparação ao contexto norte-americano (HANCHARD, 2001, p. 19), a despeito do fato de que a população brasileira seria, oficialmente, composta por $54,9 \%$ de negros ${ }^{11}$ - enquanto, nos EUA, a população afro-americana corresponde a quase $13 \%$ do total. Baseando-se na teoria da hegemonia de Gramsci, Hanchard tentou compreender diversos mecanismos de exclusão instituídos pelas elites brasileiras que garantiram um regime de hegemonia racial e foram utilizados como instrumento de manutenção do poder, subalternizando os negros. Partindo desse pressuposto, o autor localizou as diferentes etapas do estabelecimento do movimento negro nacional como integrante das lutas pelas liberdades democráticas, especialmente entre as décadas de 1970 e 1980. Especialmente nos trechos em que tratou do Black Soul como uma célula embrionária para a constituição de uma política racial é que Hanchard apontou criticamente para uma suposta inoperância das práticas culturais enfatizadas pelos movimentos negros brasileiros.

Embora os promotores e disc-jóqueis do Black Soul talvez simpatizassem com as atividades políticas clandestinas durante esse período, eles mesmos não eram agentes dessas atividades [...]. Apesar de suas repercussões simbólicas, as festas eram um fim em si. Daí

11 Segundo Pesquisa Nacional por Amostra de Domicílios Contínua (PNAD-C) de 2016, realizada pelo Instituto Brasileiro de Geografia e Estatística (IBGE). 
a separação entre as práticas políticas e culturais do Black Soul e de outros grupos afro-brasileiros mais explicitamente políticos da época. (HANCHARD, 2001, p. 141)

Ao desconsiderar a potência da cultura como prática de intervenção política - englobando também o candomblé e outras religiões afro-derivadas, músicos, dançarinos e outros artistas populares -, Hanchard (2001, p. 39) criticou o que chamou de estratégia "culturalista" dos movimentos negros brasileiros. Para o autor, a cultura teria sido usada como um fim em si mesma, e não como uma forma de mobilização e ação política para a luta pelos direitos civis dos negros no país. Especialmente em relação aos bailes de soul, Hanchard (2001, p. 142) considerou que movimento serviu apenas como repositório de identificação intersubjetiva e "incompleta" em sua "[...] valorização de formas de expressão pessoal e de identificação que, antes dele, eram reprimidas ou negadas pelos brancos e não brancos do Brasil”. Hanchard ainda responsabilizou as políticas de identidade desenvolvidas pelos movimentos negros brasileiros pela ausência ou esvaziamento de um projeto concreto político de enfrentamento do racismo, ${ }^{12}$ o que não se comprova, pois, em realidade, apesar de receber críticas de alguns intelectuais negros, o Black Soul trouxe para o debate público a discussão sobre a questão racial, apontando para novas formas de afirmação identitária e ação política, como discutirei nos próximos capítulos.

Outro americano, o brasilianista Bryan McCann, também produziu um interessante trabalho em 2002, "Black pau: uncovering the history of brazilian soul”. No extenso artigo, McCann se dedicou a criar uma genealogia do soul no Brasil, tanto como movimento cultural quanto em relação à própria configuração do gênero musical no mercado fonográfico brasileiro da época. Tendo a produção musical massiva como mote principal do artigo,

12 Sobre esse aspecto, a tese de Hanchard (2001) recebeu um ensaio crítico de Pierre Bourdieu e Louis Waquant, no qual acusam o autor de ser incapaz de compreender a dimensão global das experiências raciais no contexto da diáspora africana por conta de uma visão etnocêntrica e "imperialista”, que usaria como único modelo de combate ao racismo aquele praticado nos EUA, desenvolvido a partir do movimento pelos direitos civis dos afro-americanos. Para mais, ver: Bourdieu e Wacquant (1999). 
McCann não se ateve a questões como a criação de um movimento negro ou discussões a respeito de reconfigurações identitárias. Para o autor, existiu uma relação direta de causa e efeito, ou de entrelaçamento e sobreposição, entre uma produção musical local e as movimentações em torno dos bailes de subúrbio, sugerindo como momento-chave para a configuração de uma cena de black music brasileira as trajetórias midiáticas de artistas como Tim Maia, Jorge Ben Jor e Dom Salvador, dentre outros, responsáveis pela criação do soul brasileiro como um subgênero musical. (MCCANN, 2002, p. 35-34) De fato, McCann (2002, p. 40) postulou que o primeiro álbum de Tim Maia (Tim Maia, 1970, Polydor) "inaugurou o Soul Brasileiro como um subgênero vocal musical”, afirmando que o cantor foi uma espécie de retransmissor da cultura negra norte-americana - destacando o cantor inclusive como pioneiro no uso do cabelo afro no Brasil -, difundindo-a por entre seus fãs, em sua maioria concentrados nos subúrbios cariocas. Mas o autor retira de Tim Maia a responsabilidade por ter sido um porta-voz de um emergente movimento black em termos políticos, visto que o cantor dava frequentes declarações à imprensa ressaltando sua origem "mulata" ou mestiça, e não negra. (MCCANN, 2002, p. 43)

É na segunda parte do artigo que McCann se detém com mais ênfase na Black Rio, desmembrando alguns processos em relação às atividades das equipes de som, chamando a atenção para a discussão que motivou grande parte das análises a respeito dessa cena musical.

O Soul era, portanto, um fenômeno social nascido com uma luta em seu coração sobre o seu próprio significado: Seria um veículo para a consciência política negra, ou simplesmente mais um modismo pop enriquecendo promotores experientes?. (MCCANN, 2002, p. 49)

Aqui, a ideia de pop, segundo Soares (2014), se articula a modos de produção e consumo orientados pelas lógicas do mercado, compondo um conjunto transacional de imagens, sons e ícones, norteados para o entretenimento e conectados a estilos de vida e consumo juvenis. Furtando-se de oferecer uma resposta definitiva, McCann (2002) creditou as implicações políticas do movimento ao seu caráter transgressor, o que superaria fronteiras sociais a 
partir da celebração de novas formas de cultura popular diante de um aumento do poder de compra de uma classe trabalhadora negra e mestiça.

Apesar de estarem fora da academia, Assef (2003) e Essinger (2005) foram dois jornalistas que acompanharam um processo de revalorização da black music no Brasil no começo dos anos 2000, publicando reflexões importantes do ponto de vista histórico sobre essa produção musical massiva nacional. Assef, em Todo DJjá sambou (2003), se propôs a traçar uma genealogia da atividade dos DJs brasileiros de diversos gêneros musicais, abordando também a cultura da noite, a cena clubber e a produção musical dançante desde os anos 1950 até a atualidade. A jornalista deu especial destaque a determinados personagens ligados à criação do samba-rock enquanto cena musical e gênero musical paulistano. Um deles foi Osvaldo Pereira que, segundo Assef, foi o primeiro DJ de que se tem conhecimento no Brasil. Durante a juventude, o DJ Osvaldo criou a sua “Orquestra Invisível Let's Dance”, que nada mais era do que um conjunto de equipamentos de som escondido atrás de uma cortina, que animava bailes populares reproduzindo a atmosfera sonora das grandes orquestras que se apresentavam ao vivo nas festas da elite local. Osvaldo acabou por inspirar toda uma geração de DJs de black music, tanto em São Paulo - plantando a semente do movimento hip hop - quanto no Rio de Janeiro. O livro ainda teve dois capítulos dedicados aos bailes do Rio de Janeiro, desde o movimento black, passando pelo charme e funk, abordando também a evolução das discotecas que acabaram por popularizar uma sonoridade pop-eletrônica no país.

Já Sílvio Essinger, em Batidão: uma história do funk (2005), realizou uma intensa e detalhada pesquisa histórica em um livro-reportagem que representou um passo adiante em relação ao trabalho de Vianna a respeito do universo do funk carioca. O ponto de vista de Essinger é voltado para o momento da chegada do funk à grande mídia nos anos 1990, ultrapassando os limites das favelas e atingindo um público mais amplo, consolidando um mercado e estabelecendo também novos parâmetros para a produção musical popular periférica. Figuras mais contemporâneas do funk, como Mr. Catra, Bonde do Tigrão e Tati Quebra-Barraco, possuem destaque especial no livro do jornalista, oferecendo uma visão alternativa sobre a cultura das favelas cariocas. No livro, o autor concedeu especial atenção ao movimento 
Black Rio, produzindo extenso material a partir de depoimentos de personagens centrais para a cena, como disc-jóqueis e produtores que atuaram na época, chamando atenção para o desenvolvimento de uma cena musical marginal e alternativa, que manteve instáveis e inconstantes relações de aproximação e distanciamento com a grande mídia e com a indústria fonográfica mainstream.

Abordando especialmente a história de um clube social suburbano carioca que foi palco de diferentes projetos que estabeleceram novos parâmetros para exercícios da negritude carioca, Sônia Giacomini, no livro A alma da festa: família, etnicidade e projetos num clube social da Zona Norte do Rio de Janeiro - o Renascença Clube (2006), construiu uma reflexão sobre discursos e valores articulados a uma comunidade de negros ligados a uma agremiação na qual vivenciavam uma experiência de classe média ainda na década de 1950. Como espaço de desenvolvimento dessa "elite negra”, o Renascença Clube representava um território intermediário entre uma burguesia tradicional branca e grupos proletários negros mais pobres. Seus sócios e fundadores possuíam aspirações relacionadas a uma ascensão social, econômica e educacional.

O Renascença deixou sua marca na história cultural do Rio de Janeiro especialmente por conta das rodas de samba e dos concursos de misses negras, mas também foi palco de um dos bailes mais emblemáticos do movimento Black Rio. Alguns de seus sócios, organizadores e frequentadores se tornaram bem-sucedidos produtores culturais da cena black carioca ao longo dos anos 1970 e figuras de destaque no meio cultural e político negro carioca, como será discutido a seguir. Os bailes de soul do Renascença demarcaram também um contexto importante para o clube, pois estabeleciam relações concretas entre essa "elite de cor" e grupos de negros mais pobres, representando também o encontro de gerações e oferecendo um espaço favorável para o contato com uma cultura transnacional diaspóricas, em lugar de uma brasilidade. (GIACOMINI, 2006, p. 216)

É interessante que justamente de uma área a princípio distante dos estudos sobre música e identidade, veio a tese de Rita Aparecida Ribeiro, Identidade e resistência no urbano: o quarteirão do soul em Belo Horizonte (2008). O trabalho apresentado ao Programa de Pós-Graduação do Departamento de Geografia da Universidade Federal de Minas Gerais (UFMG) é um estudo 
amplo que envolve temas como organização do espaço, sociabilidades, produção midiática e apropriações simbólicas. O pensamento geográfico, nesse caso, serviu como aporte para a compreensão de processos de identificação, representação e ocupação de espaços desenvolvidos a partir do Quarteirão do Soul, em Belo Horizonte, ocupação cultural onde fãs de black music se reúnem em uma rua da cidade para se encontrar, dançar, ouvir música e celebrar memórias. No trabalho, a autora realizou diversas entrevistas com personagens-chave do movimento soul carioca, que influenciou o desenvolvimento de uma cena black em Minas Gerais. Mas a autora acaba por se apoiar excessivamente sobre ideias como "resistência”, "luta”, "dominação", deixando de lado ambiguidades, tensões e conflitos inerentes a qualquer manifestação cultural, acabando por oferecer uma visão homogeneizante, sem observar faces mais complexas do objeto em questão.

Carlos Palombini (2009) e José Roberto Zan (2005) contribuíram para o debate produzindo dois artigos importantes para a compreensão da configuração do gênero do soul no mercado musical brasileiro, apresentando o movimento black como um braço fundamental desse processo. Palombini (2009, p. 42), no extenso artigo "Soul brasileiro e funk carioca", realiza uma revisão bibliográfica profunda que contribui para a genealogia dos dois gêneros musicais enquanto momentos de "apropriação e ressignificação de músicas africano-norte-americanas por industriais e artistas brasileiros” que integraram um processo maior, relativo à própria constituição da fonografia no Brasil. Já em "Jazz, soul e funk na terra do samba: a sonoridade da banda Black Rio", Zan (2005) se atém basicamente a uma análise estrutural dos discos e da trajetória do grupo musical, que promoveu uma hibridação de gêneros musicais nacionais e estrangeiros, o que acabou por gerar, segundo o autor, uma ressignificação do samba em consonância com novos movimentos identitários "transterritoriais" e diferentes tendências musicais. Mas a relação entre os bailes de soul e a indústria fonográfica foi eclipsada no texto, pois o autor, ao replicar um trecho do livro de Vianna (1988, p. 110) referente especificamente ao contexto do funk, reitera a visão de que a Black Rio não estaria atrelada às prioridades da indústria fonográfica multinacional. Mais à frente, perceberemos que essa hipótese não se confirma, visto que as gravadoras investiram pesadamente no segmento do soul, o que gerou altos lucros, mesmo por um curto período. 
Nesse sentido, tanto Palombini quanto Zan relegaram à cena musical dos bailes black um papel secundário ou consequencial em relação a uma reorganização mais ampla da indústria fonográfica. Para os autores, a Black Rio teria sido uma reação a um estímulo do mercado, deixando de lado sua importância política, visão razoavelmente coerente com McCann (2002), mas diametralmente oposta à proposta de Ribeiro (2008), que, por sua vez, creditou às gravadoras uma ação coadjuvante, simples resposta às demandas de uma juventude negra. A autora acaba por enfocar apenas processos subjetivos de identificação sem atentar para a importância do consumo cultural como central na criação de novos segmentos de mercado e também de novas formas de cidadania e políticas culturais. (GARCÍA CANCLINI, 1997, 2008)

Outro ponto discutível é em relação à compreensão de que o Black Soul corresponderia a um momento da história cultural do negro brasileiro em que "[...] se formava um movimento social, até certo ponto itinerante [...], mas fortemente coeso a partir a criação de uma identidade coletiva”, como novamente aponta Ribeiro (2008, p. 121). O que logo se mostra contraditório, visto que, desde o seu princípio, havia tensões e diferentes propósitos, além de conexões e estreitas relações entre essa cena alternativa e o mainstream cultural carioca. Seja no trânsito de DJs entre bailes da Zona Norte e boates da Zona Sul, seja no flerte inicial, e depois confirmado, com gravadoras multinacionais na produção e circulação de discos e com a grande imprensa - mesmo que esta olhasse o movimento com desconfiança -, que correspondiam às instâncias da cultura mainstream da cidade.

Pesquisas mais recentes nas áreas de música, ciências humanas e sociais têm se voltado para a história dos bailes soul em dissertações de mestrado e teses de doutoramento. Esses trabalhos, de certa forma, possuem em comum a reflexão e a valorização, mesmo que percebendo algumas tensões, de uma nova produção cultural negra independente, lançando olhares mais complexos sobre o objeto. A dissertação de Eloá Gonçalves (2011), do mestrado em Música da Unicamp, se voltou especificamente para a trajetória da banda Black Rio, com foco na musicalidade e na análise do repertório, abordando o surgimento do grupo como consequência da movimentação em torno dos bailes e uma reação da indústria fonográfica da época, que desejava explorar esse novo segmento de mercado. A cena black de São Paulo foi o objeto da 
dissertação de Daniela Silva (2013), da área de Estudos Culturais, que buscou compreender a influência da música negra norte-americana na juventude negra de São Paulo, avaliando também seus efeitos em movimentos mais contemporâneos, como o hip hop. Os bailes black paulistanos também foram estudados por Félix (2000), que realizou uma etnografia em festas promovidas duas equipes locais a partir de um viés antropológico, refletindo superficialmente sobre a trajetória histórica dessas manifestações. Esses dois trabalhos mencionam brevemente a importância da cena musical da Black Rio para o contexto de São Paulo, compreendendo separadamente esses dois cenários e observando algumas especificidades locais.

Do campo da música, também veio o trabalho de Sabrina Lôbo Moraes (2014), que realizou uma aprofundada pesquisa histórica sobre a Black Rio e sobre o universo do samba dos anos 1970 a partir de material da imprensa da época. Moraes discute as tensões e conflitos criados no embate entre os adeptos do soul e do samba, não apenas como um reflexo de estratégias de marketing da indústria fonográfica, mas como representação das disputas simbólicas e dos julgamentos de valor entre uma produção cultural nacional e uma internacionalizada. Em 2015, foram produzidos dois trabalhos importantes como a tese de doutorado de Carlos Eduardo Paiva, sobre a soul music no Brasil e as reconfigurações na identidade negra. A pesquisa em ciências sociais destina um capítulo à Black Rio, mas discute o contexto geral da emergência do gênero do soul no país, abordando também a carreira de cantores identificados com a black music americana, como Tim Maia e Jorge Ben Jor, e os diálogos entre o soul e a Música Popular Brasileira (MPB) da época. A segunda pesquisa é a dissertação de André Garcia Braga (2015), do Programa de Pós-Graduação em Antropologia Social da Universidade Federal do Rio Grande do Norte (UFRN), A cena Black Rio: circulação de discos e identidade negra. Apesar do autor não trabalhar com o conceito de cena musical diretamente, ele aborda os processos comunicativos desencadeados a partir da circulação de discos de vinil, que serviram como instrumento para a interpretação da formação e do desenvolvimento da Black Rio, observando o consumo desses artefatos inseridos no contexto do Atlântico Negro. (GILROY, 2001) 
Ao lado de McCann, desde os EUA, Paulina Alberto, professora brasileira de história da Universidade de Michigan, propõe uma interpretação do movimento Black Rio bastante complexa e abrangente. A partir da pesquisa que deu origem ao livro Terms of inclusion: black intellectuals in twentieth-century Brazil (2011), editado pela Universidade da Carolina do Norte, nos EUA, a autora publicou o artigo "When Rio was black: soul music, national culture, and the politics of racial comparison in 1970s Brazil", que discute como os bailes soul fizeram parte de uma importante etapa da constituição do movimento negro no Brasil, especialmente no Rio de Janeiro. Apoiada em uma extensa pesquisa em jornais da época, tanto os de grande veiculação quanto publicações independentes relacionadas a grupos de militantes negros, a autora ainda usa como recurso para basear suas conclusões arquivos de investigação da polícia secreta da ditadura, oferecendo uma visão bastante ampla sobre como a sociedade da época encarava o soul, seus participantes, suas modas e as políticas raciais decorrentes do fenômeno. A interpretação desses debates públicos, por si só, representa um rico material que permite uma percepção mais acurada de como participantes da cena black e a sociedade em geral tentavam definir raça e cultura nacional em um contexto de intensos debates políticos e posicionamentos radicais, discussão que irei aprofundar nas próximas seções.

Em meados dos anos 1970, o Brasil testemunhava uma lenta abertura, que relaxou a censura e as tentativas de controle sobre reuniões e ajuntamentos públicos, favorecendo o aparecimento de uma maior diversidade de expressões culturais públicas. Sob a pressão de setores moderados da sociedade civil, o regime militar dava início a um período de distensão lenta e gradual durante o governo Geisel (1974-1979). (FERREIRA; GRYNSZPAN, 2000, p. 133-134) Esse foi um momento-chave na trajetória da política brasileira, caracterizado especialmente pela realização de eleições para escolha indireta de governadores, vereadores, deputados e um terço do Senado, garantindo certa dose de liberdade desde a edição do Ato Institucional 5 (AI-5) em 1968. Tanto Dunn (2009) quanto Cavalcanti (1981) consideram o Black Soul como um braço da contracultura brasileira, no sentido de criação de uma produção cultural alternativa, divergente, instigante e fundamentalmente jovem, que se 
interessava menos pelo protesto político convencional e mais pela articulação de novas identidades pessoais e coletivas.

Heloísa Buarque de Hollanda (1992) observa que a contracultura urbana do início da década de 1970 tendia a se identificar menos com o povo ou com o proletariado revolucionário e mais com minorias raciais e sexuais. Isso propiciou, no Brasil, "um encontro direto, face a face, entre setores jovens marginalizados e setores jovens economicamente privilegiados, nas grandes cidades brasileiras”. (RISÉRIO, 1981, p. 23) Nesse sentido, o movimento Black Soul não se enquadraria como um braço da contracultura brasileira, mas com ela dialogava, ajudando a trazer para a esfera pública o debate sobre o lugar social da diferença, sem se opor ao mundo social e, principalmente, ao mercado, formando diversas alianças estratégicas que refletiam a transição de um paradigma político-cultural para uma perspectiva mais individualista.

A ênfase no indivíduo que caracterizava a cena black também convergia com a proposta da Segunda Onda do feminismo, que propagava o lema de que "o pessoal é político", conjugando a luta contra diferentes opressões com discussões relativas à cultura do cotidiano e à intimidade da vida privada. Mas o Black Soul divergia fundamentalmente da postura contracultural, que implicava uma noção de indivíduo da qual estaria excluído, ou ao menos sublimado, o seu caráter de sujeito social. (CUNHA, 2009) Ou seja, para os contraculturais, o indivíduo definia-se mais pela sua subjetividade, voltando-se para seu mundo interior em oposição ao mundo social - que englobaria a sociedade burguesa e capitalista, o status quo, o mundo do trabalho, o dinheiro, as religiões institucionalizadas, as estruturas tradicionais da sociedade. E, como notaremos a seguir, tanto os frequentadores quanto os organizadores, artistas e DJs da cena black demandavam por inserção social e ansiavam por exercitar seu poder de compra, utilizando, inclusive, recursos inseridos no capitalismo global, fazendo do consumo uma fórmula de acesso à cidadania $\mathrm{e}$ à igualdade social.

Ao analisar mais profundamente a atuação das equipes de som mais importantes do período nas próximas seções, pode-se perceber que, de forma alguma, existiam mesmas preocupações e agendas políticas na pauta dos bailes por elas organizados. Da mesma forma, esse fenômeno não decorre necessariamente de um estímulo das grandes gravadoras, interessadas em 
novos segmentos consumidores. Não havia, de forma alguma, coesão, e visões que corroboram perspectivas homogeneizantes dos processos culturais deixam de lado a noção de que a cultura é palco de conflitos e tensões em processos dinâmicos de legitimação e transformação. Os significados dos produtos culturais estão sempre em disputa, retrabalhando múltiplas identidades, cada vez mais articulados a questões mercadológicas, devendo, pois, ser repensados de formas mais sutis e complexas, evitando reduções.

\section{Hello, crazy people!}

$\mathrm{O}$ viaduto 31 de Março, construído no bairro do Catumbi, região suburbana próxima ao centro do Rio de Janeiro, esconde a história do Astória Futebol Clube, clube recreativo e esportivo construído aos pés do morro do Estácio na década de 1930. Quarenta anos depois, o Astória foi a arena da realização do primeiro baile efetivamente black de que se tem notícia no Brasil. Organizado pelo disc-jóquei Mr. Funky Santos (1950-2012), no dia 10 de novembro de 1971, o evento foi o primeiro no qual só se tocou e se dançou soul music. No entanto, Vianna (1988, p. 24-25), Essinger (2005, p. 17-18) e Thayer (2006, p. 90) consideram os Bailes da Pesada, promovidos pelos DJs Ademir Lemos e o jovem branco de classe média Newton Alvarenga Duarte, conhecido como Big Boy, na casa de shows Canecão, na Zona Sul do Rio de Janeiro, o evento fundador da Black Rio. ${ }^{13}$ De fato, o primeiro Baile da Pesada foi realizado em 12 de julho de 1970, pouco mais de um ano antes de Mr. Funky Santos realizar sua primeira festa. Como muitos outros jovens da época de todo o Rio de Janeiro, Mr. Funky, ou Oséas Moura dos Santos, foi influenciado por Big Boy, então um famoso DJ, locutor de rádio e apresentador de TV. Em seus famosos Bailes da Pesada, Ademir e Big Boy começaram a introduzir a soul music, apesar de que o rock progressivo e o pop ainda predominavam no set list da festa, de acordo com Assef (2003, p. 46). Mas o ponto alto era quando o DJ tocava algum sucesso de James Brown, lotando a pista.

13 Sobre a origem dos bailes, Dom Filó (2009) também questiona essa narrativa: "Costumam atribuir a Big Boy e Ademir Lemos, no Canecão, o surgimento do soul no Brasil. Mas isso não é verdade! O fato é que nós tínhamos intervenções no subúrbio por conta de vários outros companheiros, que se reuniam pra fazer festas nas casas". 
Eu gostava de rock, gostava de blues, gostava até de reggae, mas o soul mesmo ele ainda não tinha me despertado. E a primeira vez que eu ouvi soul foi exatamente com Big Boy. Eu ouvi James Brown. Então a partir dali eu juntei uma galera e nós começamos a pesquisar músicas. ${ }^{14}$ (RIBEIRO, 2008, p. 108)

Big Boy já difundia o soul em seus programas de rádio antes dos discos do gênero chegarem ao Brasil e foi um grande divulgador do som de James Brown, dedicando alguns minutos de seu programa diário à black music. Mas a ideia de realizar um baile que tocasse soul partiu de outro discotecário famoso na época. Pecegueiro, publicitário e empresário de Big Boy, no documentário The Big Boy Show (2004), conta:

Quem começou tudo isso foi Ademir [Lemos]. O Newton me telefonou um dia e disse: 'precisamos conversar, o Ademir da Le Bateau teve a ideia de fazer um negócio, um baile em um esquema popular em um lugar gigantesco. Parece que ele já fez contato com o Canecão’.

De fato, segundo o próprio Ademir Lemos, em depoimento ao programa Brasil Legal exibido em maio de 1991, foi ele quem contratou Big Boy para animar o baile.

Newton Duarte de Alvarenga, antes de se tornar o Big Boy (1943-1977), morava no bairro do Flamengo, Zona Sul do Rio, e gastava toda a mesada com discos, inclusive comprando muitos em São Paulo. Era fã dos Beatles, mas, atento às novidades da música pop, começou a trabalhar como programador de sequências musicais na Rádio Tamoio, ainda em 1964. Formado em Geografia, chegou a trabalhar como professor enquanto iniciava, paralelamente, sua carreira de sucesso como locutor de rádio, apresentando, posteriormente, programas na televisão e escrevendo colunas de jornal. Foi para a Rádio Mundial (860) AM comandar um programa musical que foi sucesso entre os jovens, lançando bordões inovadores como "Hello, crazy people!" e conseguindo um feito até então difícil na mídia carioca: se comunicar com o

14 Depoimento de Mr. Funky Santos publicado na tese Identidade e resistência no urbano: o Quarteirão do Soul em Belo Horizonte, de Ribeiro (2008). 
público jovem, que crescia cada vez mais, chamando a atenção da indústria musical. A Mundial pertencia ao grupo Globo, que tinha um potente sistema de transmissão que permitia que o programa de Big Boy chegasse a São Paulo e a cidades do interior do Brasil. (ASSEF, 2003, p. 37) O aumento dos índices de audiência jovem proporcionado pela programação musical oferecida pelas emissoras de TV desde os anos 1960 também gerou mudanças na programação das rádios, que se voltavam cada vez mais para esse público. Big Boy criou um personagem divertido, anárquico e espontâneo, mais próximo dos jovens, veiculando os principais lançamentos do hit-parade norte-americano e europeu. ${ }^{15}$ Se não se pode necessariamente creditar a ele o pontapé pioneiro e original na origem da Black Rio, decerto Big Boy foi o responsável pela popularização do soul nas rádios brasileiras, pois há registros de que ele foi o primeiro a tocar soul em uma emissora de rádio popular, ainda em 1967, segundo Hanchard (2001, p. 135).

O sucesso no rádio levou Big Boy para as pistas de dança, criando inicialmente o Baile da Cueca, em São Paulo, que, com uma seleção de novos hits e suas apresentações, tornaram o empreendimento um sucesso. Lançou diversas coletâneas, com os sucessos do seu baile, e simultaneamente começou a apresentar os Bailes da Pesada ao lado de Ademir Lemos, no Rio, com características semelhantes. A casa escolhida foi o Canecão, misto de cervejaria e casa de shows localizada no bairro de Botafogo, Zona Sul do Rio, reconhecido como palco de shows de grandes nomes da MPB. Os bailes eram realizados aos domingos, e o set list era "uma mistura de novidades do rock e da soul music, organizados em blocos, que eram entremeados por suas sempre transloucadas intervenções ao microfone”. (ESSINGER, 2005, p. 17) O baile foi um sucesso, contando com um público frequente de 5 mil pessoas por noite, segundo Vianna (1987, p. 51). As telas dos alto-falantes das caixas acústicas do equipamento de som eram pintadas com figuras de cartas de baralho em tinta fluorescente, que, sob o efeito da luz negra, apresentavam um

15 Big Boy foi ainda pioneiro no começo das operações da FM no país e assinou a programação da Rádio Eldo Pop, do Sistema Globo de Rádio em 1973, uma rádio de vanguarda que só tocava rock, especialmente progressivo. 
belo visual. Enquanto Big Boy era o animador, Ademir era responsável pelos sets de soul music da festa.

Você estava dançando e daqui a pouco Big Boy tocava um Pink Floyd, [do disco] Ummagumma [...]. Aí você tinha que sentar, cruzar as pernas e ascender um baseado. Ficava aquele clima de paz-e-amor. Na hora em que tocava um soul, a negada do subúrbio abria uma roda. Mas eram quinze minutinhos de alegria só e ele cortava. ${ }^{16}$ (ESSINGER, 2005, p. 19)

Antes de começar a realizar os Bailes da Pesada, Ademir Lemos Inácio (1946-1998) já era um discotecário de grande influência nas boates da Zona Sul da cidade. Lemos, ${ }^{17}$ conhecido como "Homem Baile" começou sua carreira artística como dançarino de rock em 1966, no programa Os brotos comandam, da TV Continental. (ASSEF, 2003, p. 39) O programa era comandado pelo amigo Carlos Imperial, grande nome do entretenimento e da música jovem brasileira. Os dois haviam se conhecido quando Imperial convidou Ademir para trabalhar na curadoria das músicas do seu programa Clube dos brotos, na Rádio Nacional. Mas acabou se destacando mesmo no final dos anos 1960 como discotecário em boates como Jirau e Le Bateau, em Copacabana, onde ele não apenas tocava os vinis, como animava a festa dançando e recebendo os frequentadores. Da mesma forma que Big Boy, Ademir também lançava moda: "Ele era o próprio showman, com sua cabeleira black - um estilo que começava a ser adotado por alguns jovens da cidade [...]”. (ESSINGER, 2005, p. 18) Especializado em rock e pop, fez a transição para o soul a partir dos Bailes da Pesada, gênero que acabou por dar o tom das noites dançantes no Canecão e possuía um diferencial que o distinguia de outros disc-jóqueis da época: “[...] Ademir foi o primeiro DJ brasileiro a se preocupar

16 Depoimento do Mr. Funky Santos publicado no livro Batidão: uma história do funk, de Essinger (2005).

17 Para Palombini (2009, p. 52), Ademir Lemos era mestiço, enquanto, segundo McCann (2002), ele era branco, o que pode denotar tensões nas apreensões e percepções sobre cor e raça entre observadores brasileiros (no caso, Palombini) e americanos (McCann), de acordo com as experiências culturais e raciais específicas de seus países. 
efetivamente com a técnica, e não apenas com o repertório” (ASSEF, 2003, p. 39), e assinou alguns discos de coletâneas ao longo da década, além de ter apresentado um programa televisivo na extinta TV RIO e o Som Livre Exportação, na Rede Globo. ${ }^{18}$

Sobre o repertório dos Bailes da Pesada, soul e rock possuíam o mesmo destaque na festa. Segundo o DJ Corello, em depoimento concedido a Assef (2003, p. 39), "Os dois tocavam na sequência coisas como Bobby Bloom [pop], Yes [rock] e Charles Wright [soul] sem que aquilo soasse estranho”, mas foi a black music que fez a fama do evento. Big Boy chegou a declarar à revista Rock, em 1974: "Eles querem é soul, e mesmo assim James Brown. Não aceitam música branca, mais lenta, sem a bateria marcada”. (ESSINGER, 2005, p. 30) Os bailes de Big Boy e Ademir Lemos se tornaram um marco na vida noturna do Rio de Janeiro, possibilitando que os dois discotecários se tornassem grandes nomes do show business nacional. Vianna (1988) ressalta que o evento atraía frequentadores tanto da Zona Sul quanto da Zona Norte da cidade, demonstrando uma frequência mais eclética e um mote mais democrático, o que foi um marco importante, pois "havia toda uma discriminação, o povo não atravessava o túnel”, como comenta a ex-esposa de Big Boy, Lúcia Duarte, em entrevista ao programa de TV De lá Pra Cá (2014). ${ }^{19}$

E já em 1970, lançaram, em LP, a coletânea Baile da Pesada (Top Tape, 1970), uma seleção do repertório musical que integrava o set list dos bailes, com faixas intercaladas por locuções e vinhetas mixadas às músicas, a fim de reproduzir em disco a atmosfera das domingueiras no Canecão. As faixas eram compostas por sucessos da soul music, mas também do pop-rock americano, gênero musical até então predominante dentre o segmento de música estrangeira que chegava ao Brasil. Esse formato de gravação em disco de coletâneas de músicas compiladas por um DJ, que ainda por cima dava nome ao disco, era ainda inédito no mercado brasileiro. E passou a ser um modelo recorrente, potencializando ainda mais a divulgação do nome do DJ ou da

18 No final dos anos 1980, Ademir Lemos lançou-se como cantor de funk, gravando, em 1989, a "Melô do Arrastão". Em 1991, lançou o disco Um senhor baile com o sucesso "Rap do Rapa", com samples das músicas "Money for nothing", do Dire Straits, e "Cocaine", de Eric Clapton.

19 Programa De Lá Pra Cá, com direção de Carolina Sá. TV Brasil, Rio de Janeiro, 23 jan. 2014. 25 min. 
equipe de baile e possibilitando que as pessoas levassem para casa as gravações que dançavam nas festas, além de aumentar a circulação dos catálogos e lançamentos das gravadoras.

Apesar do sucesso, os DJs ficaram impossibilitados de continuar no Canecão, cuja administração preferiu receber o cantor Roberto Carlos para uma longa temporada, o que ocuparia a agenda da casa inclusive aos domingos. ${ }^{20}$ Lemos, percebendo a adesão da população da Zona Norte, resolveu transferir suas festas para os clubes do subúrbio, com o objetivo de aproveitar o emergente mercado dos bailes black. Por já possuir um maior capital para investir em aparelhagens de som importadas e por também ter mais acesso aos últimos lançamentos da música negra norte-americana, sua equipe se tornou uma das mais bem-sucedidas da cena soul, cobrando em torno de mil dólares por um típico baile de final de semana. (MCCANN, 2002) Junto com Big Boy, decidiram excursionar por várias cidades, sendo pioneiros na realização de turnês nacionais só de DJs, trazendo para o trabalho do disc-jóquei o status de artista de sucesso. Outro DJ que alcançou fama e levou o soul para as boates da Zona Sul; também realizando bailes no subúrbio, foi Monsieur Limá, o Raimundo de Lima Almeida. Como Big Boy, Limá também apresentou programas de TV - Rio By Night Avec Monsieur Limá, na TV Tupi-, apresentando-se com roupas brilhantes e espalhafatosas com altos sapatos plataforma. (ASSEF, 2003, p. 40) O DJ também lançou várias coletâneas em disco e manteve-se em atividade com bastante sucesso no momento da transição do soul para a discoteque.

\section{Bailes $100 \%$ soul}

O crédito a Big Boy é importante para a compreensão daquele momento, pois foi o responsável pela difusão inicial da soul music no Rio de Janeiro em

20 Ademir Lemos, em depoimento a Vianna (1987, p. 51), conta sua versão do fato: “As coisas estavam indo muito bem por lá. Os resultados financeiros estavam correspondendo à expectativa. Porém, começou a haver falta de liberdade do pessoal que frequentava. Os diretores começaram a pichar tudo, a pôr restrição em tudo. Mas nós íamos levando até que pintou a ideia da direção do Canecão de fazer um show com Roberto Carlos. Era a oportunidade deles para intelectualizar a casa, e eles não iam perdê-la, por isso fomos convidados pela direção a acabar com o baile". 
uma época em que o acesso a uma produção midiática internacional era ainda difícil, especialmente para jovens da periferia. O rádio, pois, assumia um papel logo também adotado pelos disc-jóqueis dos bailes, de mediador e difusor de uma cultura globalizada por entre uma população menos favorecida. Com 20 e poucos anos, Oséas Santos também era um dos ouvintes de Big Boy. O jovem era morador de uma favela no Morro da Mineira, no bairro do Catumbi, Zona Norte do Rio de Janeiro, região periférica e marginalizada da cidade. Junto com alguns amigos, organizava pequenas festas de bairro - na época, chamadas de "festas americanas" ou "hi-fis" -, que eram reuniões informais em que os convidados levavam comida e bebida e dançavam ao som das últimas novidades da música norte-americana. O costume da realização de pequenas festas, bailes, quermesses que tocavam sucessos populares para o entretenimento de jovens dos subúrbios e periferias era algo frequente e constante, representando uma forma de lazer para um público de menor poder aquisitivo. ${ }^{21} \mathrm{O}$ jornalista, ator e cineasta independente Ras Adauto, que participou ativamente da Black Rio, aponta que o soul já se difundia pelo subúrbio desde os tempos da Jovem Guarda, em uma etapa posterior ao rock'n'roll:

\begin{abstract}
Eu venho de Padre Miguel e foi ali que eu ia às festinhas de um pessoal que fazia bailes nas suas casas. [...] Já tinham bailes nos subúrbios, como no Greip da Penha e em Realengo, que tocavam soul, e havia as festas soul nas casas das pessoas, no quintal, e depois isso 'desceu' para o centro. Os bailes nascem nos guetos e desaguam pelo Rio de Janeiro todo, $e$ foram capitalizados pelo pessoal das rádios da Zona Sul. ${ }^{22}$
\end{abstract}

21 É interessante notar como esse tipo de organização de evento cultural popular amador era também percebido no contexto americano, nas rent parties ou "festas de aluguel", realizadas nas favelas do Harlem ou de Chicago, no começo do século, em que negros se reuniam para ouvir e dançar jazz tocado ao vivo, nas block parties ou "festas de quarteirão", realizadas já nos anos 1960 e 1970, em espaços públicos como praças, parques e quadras esportivas em bairros negros americanos, animados por música eletrônica, e nos sound system jamaicanos, que se baseavam em sistemas de som potentes que animavam festas realizadas nas periferias de Kingstom desde os anos 1950. O som desses sistemas sonoros possuía características particulares como a ênfase nas frequências de graves e na questão estética, possibilitando novas formas de consumo popular. (GILROY, 2001)

22 Jornalista e militante. Entrevista concedida à autora por telefone, Rio de Janeiro, em 2 fev. 2016, telefone. 
Já nos anos 1960, Assef (2003, p. 25) menciona a existência de vários DJs e grupos de baile em São Paulo que realizavam festas soul e samba-rock como os Black Brothers, Os Primus, Lancaster e Sacudim, dentre outros, já em um formato mais profissional em relação ao contexto carioca. Nos bailes suburbanos do Rio de Janeiro, naquele tempo, o que agitava as pistas era a prática da dança entre casais formados, em sua maioria, por negros pobres e de classe média baixa, ao som de hits dançantes da MPB, sambas e musicas românticas internacionais. Mas já havia influências do soul americano em noites animadas por grupos como Devaneios, Brasil Show, Copa 7 - ainda hoje em atividade - e os conjuntos de Ed Lincoln e Lafayette. Como sinaliza Essinger (2005, p. 15), "Era o programa certo para todos os fins de semana do ano, mais até do que as rodas de samba, às quais o subúrbio sempre é associado”.

Para a jornalista e crítica Ana Maria Bahiana (1980, p. 49), os bailes de soul

surgiram exatamente dos bailes de rock, prática comum nos subúrbios cariocas e paulistas no início da década. Com grupos ao vivo e depois, cada vez mais, com música em fita, esses bailes misturavam, inicialmente, rock e soul, escolhidos pelos padrões mais dançáveis.

Ao final dos anos 1960, quando o rock deixa de assumir contornos mais dançáveis, passa a ser maciçamente substituído pelo soul e por uma produção pop dançante brasileira - de artistas como Wilson Simonal, Jorge Ben Jor e The Fevers. Esse movimento de bailes voltados para um público negro, animados por música norte-americana, também já ocorria em São Paulo desde 1967, segundo Silva (1998, p. 73), quando foi criada a Chic Show, primeira equipe profissional de baile a se formar na cidade voltada para o segmento da black music, logo seguida por outros empreendimentos, como as equipes Black Mad e a Zimbabwe, ambas criadas em 1975.

Foi nas pequenas festas do subúrbio, por volta de 1969, que Oséas deu seus primeiros passos como disc-jóquei, tocando seus discos em uma vitrola barata. Oséas era uma espécie de líder de uma turma de roqueiros do Morro da Mineira e idolatrava Led Zeppelin e Jimi Hendrix, mas já ostentava um grande penteado afro. Até então, o jovem trabalhava como auxiliar de palco de um grupo de carioca de rock e, logo depois, foi contratado para prestar 
serviço para a então famosa banda de Jovem Guarda Renato e seus Blue Caps. Nessa função, aprendeu a trabalhar com som e iluminação, o que possibilitou um conhecimento fundamental para o sucesso de seus bailes. Com a fama nas redondezas dos hi-fis que organizava, o jovem resolveu arriscar, inspirado pelos bailes de Ademir Lemos, de quem era fã confesso: "Ele foi meu ídolo, esteve sempre à frente". ${ }^{23}$ (ASSEF, 2003, p. 47) Junto com sete amigos, alugou alguns aparelhos de som primitivos e pouco sofisticados - mais exatamente dois toca-discos, alguns amplificadores e seis caixas de som, segundo Essinger -, contando com a boa vontade dos donos do Astória Futebol Clube, que cederam o espaço por uma noite para a realização de um baile maior. Construído na década de 1930, o clube chegou a abrigar um time de futebol e conquistou alguns títulos de importância local. Frequentado pela classe média da região, começou a entrar em declínio nos anos 1970, e a realização de bailes populares era uma alternativa para conseguir mais dinheiro para a manutenção das instalações. Para Frias (1976, p. 4), o DJ contou como ajudou a criar um nicho de mercado:

Comecei fazendo um soul diferente do de Big Boy. Era o seguinte: o soul que Big Boy lançava era bacana, mas não era aquilo que o pessoal queria. Ele tinha uma boa discoteca, mas começou a ficar ultrapassado, porque o negócio dele era mais comercial. Aí eu entrei com um soul pesado, marcado, e apanhei o público de Big Boy. É por isso que a rapaziada me considera assim uma espécie de pai do soul. Comecei a descobrir nas importadoras um som que ninguém curtia. Foi em cima desses que eu fiquei.

O dinheiro angariado com a venda prévia de ingressos deu apenas para financiar o som, e a iluminação foi feita só com um feixe de luz sobre todo o salão: "era uma pessoa em cima de uma cadeira fazendo movimentos, essa era a iluminação", lembrou Dom Filó em entrevista ao programa Caminhos da reportagem, em 2014. A precariedade da estrutura não impediu que comparecessem à festa em torno de 1.500 pessoas, um sucesso para os padrões

23 Depoimento de Mr. Funky Santos publicado no livro Todo DJ já sambou: a história do disc-jóquei no Brasil, de Assef (2003). 
da época, especialmente por não ter havido uma maior divulgação além do "boca a boca" informal. Para animar o público quase majoritariamente negro, Oséas fazia a mixagem das músicas na chave do próprio amplificador e, além de discotecar, descia do palco e conversava com os frequentadores, como um mestre de cerimônias. Mesmo tendo prejuízo, esse primeiro baile fez história, e o até então disc-jóquei amador decidiu se profissionalizar e fundou sua primeira equipe, a Pôr do Som: "Então Santos e a Equipe Por do Som foi a primeira festa black, a primeira festa negra, $100 \%$ negra nesse país”. ${ }^{24}$ (RIBEIRO, 2008, p. 109) Outros nomes para o empreendimento foram adotados, como Santos Equipe, Curtisom, Santos Equipe de Soul, Brazilian Santos, "até que alguém lá falou que eu era o Mister Funky Santos e o negócio começou a fluir”. ${ }^{25}$ (ESSINGER, 2005, p. 18)

Escolhido o nome artístico e comandando sua própria equipe, Mr. Funky Santos passou a realizar diversos bailes em outros clubes do subúrbio nos finais de semana, buscando difundir uma sonoridade soul mais pesada e dançante, descobrindo em lojas de vinis importados, como a Billboard - que importava discos para Big Boy -, Modern Sound, Symphony, King Karol, gravações que ainda eram novidade nas pistas do Rio de Janeiro. Essas lojas, todas localizadas na Zona Sul da cidade, atraíam também DJs de São Paulo e de outros estados.

Mr. Funky pode ser considerado um dos pioneiros na criação de um produtivo modelo de entretenimento alternativo no Rio de Janeiro, e os bailes no Catumbi incentivaram a realização de festas em outros locais do subúrbio, com a criação de novas equipes, como Uma Mente numa Boa, Uagir, Black Power, Cash Box, A Cova, dentre muitas outras. Os bailes, como modos de lazer popular e espaços de consumo de novas modas musicais e culturais no Rio de Janeiro, como em outras áreas urbanas do Brasil e da América Latina, não eram uma novidade em si. Nem tampouco a composição étnica do público era um diferencial, já que eventos dançantes voltados para populações negras eram uma tradição carioca desde a abolição, como foi visto no capítulo "Bailes e clubes de subúrbio". A grande diferença, a partir dessas experiências

24 Entrevista de Mr. Funky Santos.

25 Entrevista de Mr. Funky Santos. 
iniciais, residia no fato de que os bailes nos quais se podia ouvir e dançar o soul americano começaram a ser reproduzidos em outros pontos da cidade, indo além da Zona Norte, difundindo um estilo e estimulando a criação de uma cena paralela de entretenimento e consumo periférico na cidade.

\section{As Noites do Shaft e o Clube Renascença}

Foi após uma ida a um baile de Mr. Funky Santos, no Clube Astória, que Dom Filó teve a ideia de levar para o Clube Renascença uma proposta semelhante: "Vimos que poderíamos fazer a mesma coisa no Renascença, mas com um diferencial: a consciência negra”. ${ }^{26}$ (ESSINGER, 2005, p. 19) Em 1972, o Clube Renascença - antiga associação criada no Andaraí, Zona Norte do Rio, por uma classe média negra local - foi escolhido para ser o espaço de realização de uma festa com um mote marcadamente voltado para conscientização racial: as Noites do Shaft. Fazendo referência ao personagem do seriado homônimo americano, essas festas eram utilizadas por seus organizadores para propagar um discurso politizado, voltado para a formação e a valorização de uma nova imagem do negro, influenciados pela ideologia do movimento Black Power norte-americano. O Poder Negro, em sua acepção original, se referia a um conjunto de ideias e valores de afirmação e orgulho negro desenvolvido na década de 1960, tendo como um de seus principais idealizadores Stokely Carmichael, que difundia a crença da superioridade das culturas negras de origem africana.

A própria escolha do nome do evento já representava uma proposta diferenciada, mais popular e uma articulação com símbolos internacionais. Shaft era o nome do personagem principal do filme de mesmo nome, que contava as aventuras de um detetive negro, que propunha uma visão positiva e um protagonismo do negro em uma narrativa relacionada às experiências das populações negras norteamericanas. O filme, protagonizado pelo ator Richard Roundtree, ganhou três sequências dirigidas por Gordon Parks. Lançado pela MGM em 1971, teve um grande orçamento e recebeu o Oscar de melhor canção no ano seguinte com uma composição de Isaac Hayes, um dos

26 Depoimento de Dom Filó publicado no livro Batidão: uma história do funk, de Essinger (2005). 
maiores nomes do soul norte-americano e um dos artistas mais engajados da época. Sucesso comercial e de crítica, Shaft (Stax Records, Entreprise Records, 1971) é o trabalho mais conhecido de Hayes, que deu nome ao disco mais lucrativo lançado pela gravadora de black music Stax. Esse foi também o primeiro álbum duplo de estúdio de um artista de Rhythm \& Blues (R\&B). ${ }^{27}$ O filme notabilizou-se por lançar um herói negro, quase um similar de James Bond, porém carregado do linguajar das ruas, mostrando um estilo comportamental e uma moda típica dos guetos urbanos afro-americanos. Shaft pode ser considerado um dos primeiros filmes que inaugurou a vertente chamada blaxploitation.

A iniciativa de criar um evento com o título do filme para celebrar o orgulho negro foi do estudante de engenharia Asfilófio de Oliveira Filho, conhecido como Dom Filó, que conseguiu convencer a diretoria do Renascença a ceder o clube para a realização de eventos culturais que atuassem como formadores de uma consciência racial e social junto à comunidade negra. A primeira atividade foi a montagem do espetáculo musical Orfeu da Conceição, de Vinícius de Moraes, com atores negros que haviam formado um grupo de teatro do qual faziam parte nomes como Antônio Pompeu, Zózimo Bulbul e Zezé Motta. Dirigido por Haroldo de Oliveira, o elenco da peça também contou com não atores frequentadoras do clube, e o cenário teve a assinatura da arquiteta Vera Figueiredo, com trilha sonora do maestro Paulo Moura. A montagem chegou a ser encenada, posteriormente, no Teatro Tereza Raquel, em Copacabana. No entanto, o espetáculo não atraiu o público esperado ${ }^{28}$ e Dom Filó, ao se tornar diretor artístico do clube, junto com o ator Haroldo de Oliveira, teve a ideia de organizar grandes bailes para, através deles, propagar mensagens de valorização da cultura negra aos frequentadores. Por meio dessas festas, seus organizadores tentavam difundir um discurso mais

27 O disco atingiu o número um da The Billboard 200 e passou 60 semanas no topo das paradas norte-americanas. Os singles de "Theme from Shaft" e "Do your thing" também entraram no ranking Top 40 da parada Billboard Hot 100.

28 “[...] então a gente montou o Orfeu, aí tudo bem, um espetáculo maravilhoso, um sucesso, mas jovem negro nenhum. Ninguém tava [sic] ligado nesse troço de cultura. Eu com aquilo compreendi e entrei numa de fazer som" (Jornal de Música apud VIANNA, 1987, p. 55), conta Dom Filó em entrevista ao Jornal da Música em 1976. 
politizado, voltado para a formação e a valorização de uma nova imagem do negro. Lemas do movimento Black Power, como "I am somebody" e "I'm black and I'm proud", passaram a ser incorporados pelos frequentadores, representando uma aplicação da ideologia norte-americana do Poder Negro na vida cotidiana de jovens negros cariocas. O baile foi um sucesso e passou a atrair não somente os jovens frequentadores do Renascença como também a juventude negra de comunidades de pobres do entorno como Engenho Novo, Vila Isabel, Salgueiro, Morro dos Macacos, Andaraí, Pau da Bandeira e Cachoeirinha. (GIACOMINI, 2006, p. 210)

O Clube Renascença já levantava a bandeira da valorização da cultura negra desde sua criação. Fundado em 17 de fevereiro de 1951, a agremiação reunia, na época, 29 sócios, 11 homens e 18 mulheres, todos negros, que buscavam reforçar a existência de uma "elite" negra, em vias de ascensão social. De fato, a primeira diretoria do Renascença era composta por profissionais liberais que possuíam títulos universitários, o que era um grande diferencial quando se pensa no índice de escolaridade média da população carioca e, em particular, da população negra brasileira na época. Dentre as profissões dos coordenadores do Renascença, estavam um ourives, duas médicas, um médico, um professor de música e um advogado, que presidia a chapa da direção. Apesar do bom nível de escolaridade e de já integrarem uma classe média emergente, esses indivíduos não eram aceitos nos clubes tradicionais em função de sua cor. E o Renascença foi criado com o propósito de servir como espaço de convivência comunitária e também um local de resistência, conscientização e valorização racial.

Localizando-se inicialmente no bairro de Lins de Vasconcelos, o clube foi posteriormente transferido para o Andaraí, ambos bairros da Zona Norte, próximos ao centro. Essa região era tradicionalmente habitada por uma classe média e média-baixa e representava uma área de encontro entre "o morro e o asfalto”, também concentrando um emergente grupo de famílias negras em ascensão formadas por profissionais liberais, funcionários públicos e militares. O nível de renda e escolaridade de seus fundadores também ajudou a determinar um viés político-ideológico da vida social do clube nos seus primeiros anos, marcado por atividades que preenchiam rotineiramente a vida social dos seus associados desde que contribuíssem para "o aprimoramento 
dos jovens e estimulassem a socialização e difusão de certos símbolos da cultura clássica ou erudita”, como pontua Giacomini (2006, p. 32).

É importante frisar aqui que essa cultura "clássica" e "erudita" podia embaralhar tanto produtos culturais característicos de uma elite ocidentalizada - como a prática esportiva do xadrez, a leitura de cânones literários, a audição de música erudita tradicional -, como também se referia ao contato com textos produzidos por teóricos da negritude, enquanto corrente literária, como a obra do poeta antilhano Aimé Césaire e do político e escritor senegalês Léopold Sédar Senghor, ligados também ao movimento pan-africanista. A articulação a correntes clássicas ideológicas do pensamento racial estava inclusive representada na própria escolha do nome da agremiação. O Renascença teve seu título inspirado no movimento artístico-literário Harlem Renaissance, promovido nos anos 1930 no bairro negro nova-iorquino do Harlem por intelectuais negros como forma de criticar a discriminação racial e a desigualdade econômica, buscando uma autonomia e uma originalidade cultural para a população afro-americana. Os integrantes do clube Renascença, assim, se alinhavam a bases ideológicas clássicas ocidentalizadas que buscavam uma valorização do homem negro a partir da construção de um pensamento erudito como forma de afirmação e legitimação em sociedades racializadas.

A proposta da consolidação de uma elite intelectual negra, da mesma forma que era pensada no Harlem Renaissance, também encontrava ecos na configuração de um projeto para os frequentadores do Clube Renascença como um espaço de distinção. Diferentes formas de sociabilidade e de eventos festivos foram experimentadas, revelando, igualmente, distintas concepções de público e privado e também do que seria "ser negro". Efetivamente, o Renascença, em suas práticas iniciais, programações culturais e eventos sociais, reproduzia formas de exclusão ou de separação entre trabalhadores proletários e a pequena burguesia negra em ascensão que compunha seus associados, de maneira bastante semelhante ao que ocorria nos clubes da elite branca que barravam o ingresso de negros, conforme aponta Martins (2010, p. 122).

Nos anos 1960, uma mudança de rumos promove uma "popularização" das atividades do Renascença, com a incorporação de rodas de samba com artistas famosos e dos concursos de misses negras, muito valorizados na época, 
que obtiveram grande sucesso e apoio popular geral. Inclusive, uma das misses do Renascença, Vera Lucia Couto, foi vencedora do concurso de Miss Estado da Guanabara e ficou em segundo lugar no Miss Brasil de 1964. De fato, entre os anos 1960 e 1970, o clube integrou-se à geografia da cidade, cuja fama e a frequência ultrapassou os limites do subúrbio carioca. A festejada eleição de Vera Lúcia Couto como Miss Guanabara foi vista por muitos, se não pela maioria dos sócios, como uma vitória da negritude, quase um resultado memorável do esforço coletivo do grupo.

Por conta do sucesso de suas misses, o Renascença passaria a ser conhecido - e também reconhecido por seus próprios associados - como o "clube das mulatas”, o que, na época, foi alvo de julgamentos contraditórios. Um dos críticos dessa vertente era Dom Filó, que já desenvolvia um trabalho voltado para o combate à Doença de Chagas nas comunidades no Morro dos Macacos, em Vila Isabel e no Salgueiro. Filó teve uma trajetória atípica para um jovem negro da época. Nascido em 1949, passou a adolescência no bairro do Jacaré, Zona Norte. Filho de mãe empregada doméstica, o pai era mecânico e entrou no ramo de compra e venda de carros, até se tornar um bem-sucedido dono de uma agência de automóveis. A melhora nas condições de vida possibilitou que a família matriculasse o filho no curso de Engenharia Civil em uma faculdade particular, a Fundação Souza Marques - que era propriedade de uma família negra. Filó conta que "lá, entre os 43 alunos da turma, só havia quatro negros. Eu e outros três, todos eles militares. Eu com meu cabelo black power - e, às vezes, com tranças de barbante - tamanco, bolsa de pano, calças pantalonas. Era hippie”. (ALMADA, 2013) Além de estudar, Filó também comprava e revendia calças Lee, muito desejadas na época, além de perfumes importados, como o argentino Lancaster, para ajudar nas finanças. Ao completar 18 anos, ganhou um carro do pai, o que deu a Filó certa facilidade para circular pela noite carioca, conhecendo diferentes espaços de lazer, entretenimento e boemia.

Eu, de carro, me deslocava tanto para os bailes de grupos musicais como o Copa Sete, Devaneios, Lafayete, The Pops, na Zona Norte, como para o Beco da Fome, na Zona Sul da cidade, onde se reuniam artistas, e conheci gente como Jorge Ben Jor, Tim Maia, entre 
muitos outros. Minha identificação era com os bailes de dança de salão, mas isto antes de conhecer o soul. (ALMADA, 2013)

O Beco da Fome, contemporâneo do Beco das Garrafas, também se localizava em Copacabana, mas permaneceu em atividade após os anos 1960. Estava localizado na Rua Prado Júnior e reunia profissionais que trabalhavam até tarde da noite ou na própria noite, como jornalistas, policiais, cafetões e pessoas envolvidas com atividades de origem duvidosa. No Beco, estavam localizadas em torno 18 cantinas, que ofereciam cardápios a preços populares, e muitos músicos frequentavam o local após seus shows, bem como diversas outras pessoas em busca de um local alternativo para a diversão - o espaço foi destruído e hoje em dia dá lugar a um edifício. Além de frequentar diferentes pontos da noite carioca, Filó também se interessava pelas obras de intelectuais negros, como os americanos Malcolm X e Martin Luther King e os africanos Agostinho Neto e Samora Machel - respectivamente, os primeiros presidentes de Angola e Moçambique. No Renascença, realizava palestras e exibia alguns filmes de jazz cujas cópias eram cedidas pelo Instituto Cultural Brasil-Alemanha (ICBA), mas foi por meio dos bailes que percebeu um potencial maior de conscientização. Se nos anos 1950 a referência do Renascença era uma classe média idealizada, amante de saraus, e nos anos 1960 o projeto do clube tinha uma inclinação para a celebração da cultura negra nacional, nos anos 1970, buscou-se uma prática fora dos modelos consagrados, seguindo os passos dos movimentos negros norte-americanos e flertando com algumas propostas ideológicas do grupo Black Panthers. Isso também gerava conflitos e tensões entre as gerações mais velhas do clube, que inicialmente não toleravam ceder o espaço para um evento festivo tido como menos legítimo e distante da tradição. Os choques geracionais provocados pelo soul também se relacionavam à forma como os bailes abordavam abertamente as questões da autoestima negra e da luta contra o racismo, de acordo com Hanchard (2001, p. 136): "Em muitas ocasiões, as moças e rapazes que participavam do Black Soul entraram em conflito com os pais ou se viram como catalisadores de familiares que, até então, nunca haviam enfrentado as questões de opressão e identificação raciais”. Essa nova geração que passou a organizar e modificar a programação cultural do clube era influenciada por 
outros valores e visões. Dom Filó, juntamente com seus amigos, pensava em novas formas de ocupar aquele espaço sem abrir mão do mote que havia marcado a história do clube.

Eram herdeiros, mas também críticos da tradição construída ao longo da história do Renascença, oriundos de uma classe média negra emergente, alguns estudantes de cursos universitários. Alguns poucos tinham acesso a espaços sociais e de lazer da elite da Zona Sul carioca, e acesso à informação e geral, que vão, aos poucos, construir um projeto cultural e político com um cunho militante objetivando contribuir para a criação de uma consciência negra e para a constituição das primeiras bases de um movimento negro organizado. (GIACOMINI, 2006, p. 190)

Os bailes black passaram a disputar espaço, atenção e simpatia com as tradicionais rodas de samba realizadas no Renascença. Para Giacomini (2006), esse momento foi conflituoso, pois, na construção das acepções de uma identidade negra para o clube e seus sócios mais antigos, havia uma oposição a um sentimento racial importado dos Estados Unidos e presente no consumo da soul music, a despeito do fato de que a associação foi inicialmente influenciada por intelectuais afro-americanos clássicos ligados ao Harlem Renaissance. Para as gerações mais antigas de sócios, a construção da identidade negra deveria ser pensada a partir de traços mais nacionais e locais, como o samba, que seria uma manifestação cultural mais autêntica. Mas essas discussões internas não impediram o sucesso das Noites do Shaft, que durou três anos, sendo realizadas todos os domingos ininterruptamente. Mais que um simples baile, o evento emulava uma nova maneira de ser negro, apresentando um universo contemporâneo de imagens e referências e rejeitando o lugar a que se pretendia tradicionalmente atribuir o negro brasileiro, ligado a símbolos como samba, morro, favela, carnaval.

Com o foco na autoestima, a equipe de produção das Noites do Shaft definiu uma estratégia para os bailes, que deveriam ser mais diretamente vinculados a questões políticas e raciais a partir da articulação a uma cultura massiva afro-americana. Com vistas a alcançar esse objetivo, um dos pontos altos da festa era a projeção de slides em um paredão branco, com imagens retiradas 
de revistas americanas voltadas para o segmento negro, como a Ebony, ${ }^{29} \mathrm{du}-$ rante a execução das músicas. Naquele tempo, o acesso a publicações internacionais era restrito, e encomendas eram feitas a raros viajantes ou a aeromoças e comissários de bordo, que traziam algumas edições clandestinamente, junto com vinis contrabandeados. Também era possível encontrar edições da Ebony em bancas que vendiam jornais e revistas importadas na Avenida Rio Branco, no centro da cidade. O mero ato de adquirir um exemplar já era uma atitude de tomada de posição política, como aponta Carlos Alberto Medeiros, militante negro, em depoimento a Alberti e Perreira (2005, p. 3):

Eu passava e via a revista, tinha até alguma curiosidade. Mas é interessante isso: até para comprar a revista a primeira vez, eu tive que romper com alguma coisa. Porque você comprar uma revista de negros tinha um significado de identificação.

Medeiros se formou em jornalismo e atuou politicamente em diversas áreas, contribuindo com muitos dos projetos culturais de Dom Filó ao longo dos anos.

Além das fotos, nos bailes, eram projetados trechos de Shaft e de outros filmes representantes do cinema blaxpoitation, como Super fly e Wattstax. Wattstax, em particular, teve um papel importante para o movimento black, oferecendo imagens, discursos e músicas aos frequentadores dos bailes. Considerado o Woodstock negro, o documentário foi lançado em 1973 e não teve exibição comercial no Brasil, sendo mostrado em alguns bailes - na íntegra ou parcialmente -, com direção de Mel Stuart, que ficou famoso ao dirigir o filme A fantástica fábrica de chocolate, em 1971. O documentário registrou o festival de música negra realizado em 1972, no pequeno bairro periférico de Watts, em Los Angeles, organizado pela gravadora Stax - na época, a principal concorrente da Motown no mercado da black music. O show era uma forma de homenagear a comunidade, que, em 1965, foi palco da Revolta Popular

29 Ebony é uma revista mensal voltada para o público afrodescendente, criada por John Harold Johnson em 1945 nos Estados Unidos e publicada até os dias atuais. Sua proposta era dar visibilidade à população afro-americana, e suas capas são dedicadas a atores, músicos e políticos negros do país. 
de Watts, um dos mais sangrentos conflitos raciais ocorridos na história dos Estados Unidos. Mas também foi uma ação de marketing interessante para divulgar o casting da gravadora a partir de um concerto com suas maiores estrelas. O público presente pôde ouvir grandes sucessos do soul, funk, gospel e blues, e a iniciativa serviu como estratégia para vincular a imagem da Stax à comunidade negra e pobre dos Estados Unidos, em oposição à Motown, que cada vez mais se voltava para o segmento consumidor pop-branco americano. Wattstax ainda mesclava as apresentações musicais com imagens da plateia e do bairro, além de intercalar depoimentos de membros da comunidade negra de Watts com esquetes de comédia do famoso comediante negro Richard Pryor, criticando o racismo e analisando com humor alguns traços da cultura negra norte-americana. O documentário captava bem o clima da época e retratava o estilo dos habitantes locais, divulgando também frases do movimento pelos direitos civis, como "I am somebody", lema que integra o célebre discurso do reverendo William H. Borders, escrito nos anos 1950, proferido no documentário por Jesse Jackson, pastor batista e ativista político norte-americano.

Nos bailes do Renascença, também eram exibidas fotos de astros da black music, como James Brown, Jackson Five e Diana Ross, e de atletas, como Muhammad Ali, a fim de inspirar a plateia com as conquistas políticas e as construções estilísticas dos negros norte-americanos, "fazendo uma espécie de introdução à cultura negra por fonte que o pessoal já conhece, como a música e os esportes", justificou Filó em entrevista ao Jornal da Música. (VIANNA, 1987, p. 55) E mescladas às imagens de celebridades - algumas poucas brasileiras, como Pelé -, eram mostradas também fotos dos próprios frequentadores dos bailes, relacionando aqueles ícones com suas próprias experiências. "Você se via na tela, a autoestima aumentava e aquilo trazia mais gente. Foi uma bola de neve". ${ }^{30}$ (ESSINGER, 2005, p. 22)

Era fascinante para os novatos e deixava ansiosos mesmo os frequentadores mais experimentados. Estar bem composto no estilo Shaft, mais que necessário, era particularmente compensador e gratificante,

30 Depoimento de Dom Filó publicado na obra de Essinger. 
o que se entende quando se tem em vista a organização e apelos da festa: slides projetados nas paredes exibiam, alternadamente, imagens do Shaft e closes dos frequentadores. Nesses instantes, o participante se via em tamanho aumentado e era visto por todos. Celebrados e cotejados, lado a lado, o Shaft e o anônimo participante da festa, ambos nas mesmas dimensões, em cada qual igualmente presentes os signos que expressavam a adesão comum ao soul, à alma e ao orgulho negros, sintetizados e coagulados, de maneira perfeita, na figura do Shaft. (GIACOMINI, 2006, p. 195-196, grifo do autor)

Além da exibição das imagens, Dom Filó interrompia a discotecagem e passava algumas mensagens, que também eram mostradas nos slides, como "O seu cabelo cresce dia-a-dia, mas o mais importante é o que está debaixo desse cabelo. O que você esta pensando do futuro?" e "Nós temos que nos organizar como negros, senão nós não vamos chegar lá”. (ESSINGER, 2005, p. 22-23) Temas como estudo, família, abuso de drogas e violência também eram abordados, em uma visão positiva dentro de uma perspectiva de ascensão social associada ao orgulho negro. E alguns ativistas negros começaram a utilizar os bailes soul como locais para buscar adeptos. Não era incomum ver em alguns bailes jovens militantes distribuindo exemplares de livros como Black Power, de Stokely Carmichael, e Os condenados da Terra, de Frantz Fanon (HANCHARD, 2001, p. 138), obras de líderes negros que discutiam a questão racial e o combate ao racismo. É importante enfatizar que, mais do que outros bailes soul da época, as Noites do Shaft tinham uma vinculação maior com a questão política negra, não apenas por serem realizadas em um clube de negros que tinha uma trajetória de valorização da questão racial, mas por serem organizadas por jovens já ligados a uma militância, ainda em fase de reorganização. Carlos Alberto Medeiros ${ }^{31}$ assume:

Eu entrei no movimento negro via baile. O mais interessante é que minha trajetória no movimento negro começou frequentando as Noites do Shaft. Foi em uma ocasião em que fiquei sabendo de uma reunião que seria realizada no Centro de Estudos Afro-Asiáticos, da Universidade

31 Jornalista e militante. Entrevista concedida à autora, em 5 dez. 2016, no Instituto de Filosofia e Ciências Humanas, UFRJ, Rio de Janeiro. 
Cândido Mendes, em Ipanema. Decidi ir a esse encontro, e a partir dali me tornei um militante.

Dom Filó, da mesma forma que Mr. Funky, criava uma nova forma de atuar, ultrapassando o simples papel de tocar músicas. Naquele tempo, os DJs, mesmo que famosos, tocavam de costas para o público, de acordo com Essinger (2005, p. 19). Mas, nos bailes soul, os disc-jóqueis desenvolviam performances diferentes e assumiam uma função de animadores, mestres de cerimônias, se tornando celebridades. Especialmente a questão da autoestima estimulada pelos produtores das Noites do Shaft influenciou muitas outras equipes, que, em seus bailes, passaram a premiar os cabelos "blacks" mais bonitos, ou realizavam concursos para escolher os frequentadores mais parecidos com astros do soul, como Isaac Hayes ou James Brown. No baile da SGP no Mourisco em 1976, o participante mais parecido com Isaac Hayes concorria a uma caderneta de poupança no valor de mil cruzeiros como prêmio. (FRIAS, 1976, p. 3) Já em outros eventos, as premiações eram destinadas aos melhores dançarinos. Essa valorização também das pessoas comuns ao lado dos artistas famosos era uma estratégia também adotada nos próprios panfletos e cartazes de divulgação das festas, em que fotos de frequentadores ilustravam as peças publicitárias junto com rostos de celebridades dos bailes, como o cantor Tony Tornado e o DJ Monsieur Limá.

O fato de ser um dos poucos jovens negros a possuir um carro na época permitia que Filó circulasse pela noite carioca e descobrisse onde poderia conseguir discos inéditos para seus bailes, desenvolvendo novas oportunidades de negócios na área da cultura e do entretenimento. O soul ainda era um gênero pouco explorado em termos de segmento noturno, pois não era a música mais tocada nas boates e emergentes discotecas da Zona Sul. Disc-jóqueis de casas famosas, como Le Bateau, Jirau, One Way, dispensavam os discos de soul que chegavam, e os DJs dos bailes black começaram a negociar para conseguir esse material, criando canais exclusivos de acesso às novidades do gênero. "Chegava muito material black e eles só tocavam Sex Machine”. ${ }^{32}$ (ESSINGER, 2005, p. 19-20) E, desse modo, nomes do soul

32 Depoimento do Dom Filó. 
norte-americano, como Rufus Thomas, Isaac Hayes e Aretha Franklin, passaram a fazer parte do acervo dos DJs cariocas do subúrbio e do gosto de milhares de frequentadores dos bailes.

\section{O soul em alta velocidade}

As Noites do Shaft fizeram enorme sucesso, e o baile passou a não mais caber no Renascença. Em 1975, a mudança para outros espaços, como o Clube Maxwell e o Cascadura Tênis Clube, acarretou modificações na produção da festa, além de gerar um aumento do público. A mensagem política direta presente nos discursos contra o racismo e nas imagens teve que ser amenizada para que o baile pudesse ser realizado em clubes de classe média da Zona Norte, frequentados por um público mais misto. Dom Filó, junto com alguns amigos, decidiu então criar a equipe Soul Grand Prix, que tinha como slogan "Soul em alta velocidade". Sem abandonar a estratégia da projeção de imagens de temática negra durante os bailes, estas passaram a ser alternadas com cenas de pilotos de Fórmula Um, esporte muito em voga na época. Essa estratégia ajudava a dar um tom menos politizado ao baile, agora mais frequentado por jovens brancos. (HANCHARD, 2001, p. 136) Entretanto, o mote da conscientização racial não foi totalmente abandonado, e as festas organizadas pela SGP continuaram a ter uma pretensão mais didática. Projeções de personalidades negras continuaram ilustrando os bailes, com fotos de músicos como Duke Ellington e Dizzy Gillespie, em uma espécie de introdução à cultura negra.

A SGP se estruturou como uma das principais equipes de som do Rio de Janeiro e fez história no universo do entretenimento carioca, desencadeando uma nova fase da cena Black Rio. (FRIAS, 1976, p. 4) A equipe foi a primeira a realizar bailes também na Zona Sul, em bairros como Botafogo, Horto e Jardim Botânico. Em seu auge, a equipe era composta por um DJ principal, Luizinho, enquanto a parte empresarial ficava a cargo de Nirto Batista de Souza, primo de Dom Filó, que criou alternativas comerciais para o crescimento da equipe, produzindo bailes cada vez maiores e mais lucrativos em vários pontos da cidade, todos os dias da semana, sempre lotados. (VIANNA, 1987, p. 54) 
A equipe conseguiu o patrocínio de uma loja no Leblon, Curtisoul, que comprou o equipamento de som e deu o nome ao empreendimento, mas que logo foi substituído por "Soul Grand Prix". A mudança do nome da equipe não agradou aos donos da loja, que resolveram acabar com a parceria e pegaram de volta os equipamentos. Então, de forma artesanal, Nirto e Luizinho uniram duas caixas de som, com quatro woofers de 12 polegadas cada uma, em um sistema de som amador, mas que podia ser transportado facilmente, facilitando a circulação da equipe pelo subúrbio. Outras equipes copiaram a ideia, mas com equipamentos cada vez maiores e mais potentes. "As equipes passaram a empilhar caixas de som, formando enormes paredes ou muralhas que se tornaram marca registrada desses bailes". (HERSCHMANN, 2000, p. 23) Os também chamados "paredões de som" podiam ser dispostos de acordo com o espaço disponível, espalhados pelo salão ou montados um sobre os outros como um jogo de blocos. Na contracapa do LP de 1978 da Furacão 2000 (ABC Records - Phonodisc), Rômulo Costa escreve:

São 50 caixas de som em suspensão acústica, 8 caixas de som para acústica, mesa de som com 19 canais, câmara de eco para efeitos especiais, 16 amplificadores transistorizados de 250 watts cada, sofisticado sistema de iluminação que vai das luzes rítmicas às cadavéricas [...].

Com o aumento dos lucros, a SGP adquiriu um sistema de som e luz mais poderoso, incluindo luzes estroboscópicas e projetores coloridos, dando ao baile uma atmosfera pirotécnica e onírica, inspirada também na ambientação das recentes discotecas. Outra característica da equipe foi o desenvolvimento de estratégias de marketing alternativas para divulgar a marca dos seus bailes, que contavam não apenas com o carisma do mestre de cerimônias Filó, mas também com um visual diferenciado ostentado pelos integrantes da equipe, que também contava com um grupo de dança chamado Angola Soul, com uma média de 30 integrantes, que animavam os bailes. Duplas e grupos de dança eram um recurso frequentemente utilizado por algumas equipes. Em geral, não eram bailarinos formais, mas fãs que compareciam frequentemente aos bailes e chamavam a atenção pela maestria na dança e pela aparência, 
sendo contratados informalmente pelos donos das equipes - muitas vezes pagos apenas com discos ou entrada gratuita nos bailes. Outra marca que tornou os bailes da SGP famosos eram as intervenções realizadas no meio do baile, que sempre aconteciam entre meia-noite e duas da manhã. Um hit musical dançante e "explosivo" sinalizava esse ápice, com luzes estroboscópicas que começavam a piscar com mais intensidade, enquanto uma chuva de filipetas era disparada: era o auge do baile. Esse momento poderia corresponder à execução de músicas famosas, como os hits "Soul Power" ou "Sex Machine", de James Brown. Esse tipo de apresentação, junto com a utilização de grandes conjuntos de caixas de som, acabou se tornando um padrão incorporado por todas as equipes de soul, com algumas variações, e vigora até hoje nos bailes funk e em outras festas periféricas contemporâneas disseminadas pelo país, como nas festas de aparelhagem de tecnobrega no Pará, na cena reggae maranhense e nos shows de forró eletrônico do Nordeste.

A SGP tornou-se um empreendimento grande e lucrativo e seus promotores resolveram investir diretamente no mercado fonográfico, lançando seu primeiro LP com os principais sucessos do baile em 1974, pela Top Tape, produzido por Ademir Lemos. Segundo Frias (1976, p. 3), a equipe entrava com o nome e ganhava um cruzeiro por LP editado, e as faixas eram selecionadas de discos americano. Dois anos depois, a convite do famoso executivo da Warner, André Midani, a SGP lançou seu segundo álbum, que recebeu o disco de ouro. Em 1977, a fim de driblar pressões políticas e administrativas, a equipe se tornou empresa: Soul Grand Prix Produções, ampliando a gama de empreendimentos, como realização de shows e produção de programas de rádio, lançando vários discos. A equipe produziu e acompanhou o cantor Elton Douglas em 1976, realizando o primeiro baile da SGP na Zona Sul - junto com a equipe Black Power -, no Clube Mourisco, em Botafogo. Logo depois, Filó foi novamente convidado pela gravadora para uma nova empreitada, a criação da Banda Black Rio, cujos detalhes conheceremos mais à frente.

\section{Os DJs e as equipes de som}

Muitos dos seguidores dessas equipes pioneiras resolveram iniciar seus próprios negócios. Por volta de 1976, havia centenas de equipes de soul em 
atuação no Rio de Janeiro, e o movimento migrou para São Paulo, fazendo muito sucesso, e se espalhou por outras cidades, como Vitória, Porto Alegre, Belo Horizonte, Brasília e Salvador. O movimento Black Soul se disseminava pelo país através de suas filiais Black São Paulo, Black Porto, Black Bahia e Black Uai, mas o Rio continuava sendo o centro de "produção black", e os bailes cariocas recebiam caravanas de ônibus de várias cidades brasileiras. (PEREIRA, 2000, p. 2)

O centro e o subúrbio foram tomados pelos bailes de soul, com equipes profissionais especializadas, como a Black Power, Curtisom, Alma Negra, Célula Negra, Atabaque, Revolução da Mente, ${ }^{33}$ Dynamic Soul, Hollywood, Furacão 2000, que existe ainda hoje em outro formato, voltada para o funk carioca, ${ }^{34}$ além da equipe de Mr. Funky Santos, entre muitas outras. Para Thayer (2006, p. 90-91), a Zona Norte foi a região ideal para a difusão dos bailes black basicamente por ser um espaço de ocupação predominantemente negra aberta à difusão de sonoridades massivas afro-americanas. Além disso, era uma área que contava com vários clubes recreativos e esportivos, com amplos ginásios e salões de bailes e com as quadras escola de samba, ideais para eventos com grandes públicos, já que a média de frequência dos bailes girava em torno de 5 mil pessoas, podendo chegar a 10 ou 20 mil frequentadores. Espaços de lazer suburbano importantes como o Clube Mackenzie, Disco Voador, Portelão, Cine Show Madureira, Vera Cruz, Lespan promoviam bailes concorridos, que também eram realizados em regiões mais centrais, como Cesp-Rodoviária e na sede do cordão Bola Preta. Em entrevista a Essinger (2005, p. 25), o cantor Gerson King Combo comenta:

A Zona Sul era do Big Boy e do Ademir, a Zona Portuária e o Centro eram do Funky Santos, a Zona da Leopoldina, de Méier e Cascadura, da Soul Grand Prix. Mas de Madureira para lá - Oswaldo

33 Alusão ao título do álbum duplo homônimo de James Brown Revolution of the Mind: Recorded Live at the Apollo, v. 3, Polydor, 1971.

34 A equipe de som mais famosa até hoje foi a Furacão 2000. Criada em Petrópolis, tornou-se um miniconglomerado na área de entretenimento no Rio de Janeiro, depois de ter sido comprada por Rômulo Costa, um ex-funcionário da equipe. Atualmente, a Furacão é a maior marca ligada ao funk carioca, se desdobrando em gravadora e produtora, além de realizar programas de TV e de rádio. 
Cruz, Bento Ribeiro, Marechal Hermes, Rocha Miranda, era tudo da Black Power.

No auge do movimento, as equipes e produtores começaram a organizar shows com artistas de renome nacional e internacional. A profissionalização dessas equipes de som - que, em meados da década de 1970 giravam em torno de 300, como estimava Frias (1976, p. 4) - permitia que os produtores investissem intensamente em sonorização de qualidade e divulgação. Os maiores bailes, como os festivais de equipe, chegavam a obter rendas comparáveis a de um jogo no Maracanã, de acordo com Ademir Lemos: "Um negócio desses, só à base de discos, é uma loucura. De chegar a render Cr\$ 200 mil de bilheteria por baile com eu estou cansado de ver. Uma renda que um jogo, se não tiver Vasco ou Flamengo, não atinge”. (FRIAS, 1976, p. 3)

As equipes de som - também chamadas de equipes de baile - contavam com um DJ principal e outros secundários. Basicamente, havia um discotecário responsável por comandar os toca-discos, enquanto outro profissional controlava os amplificadores, e havia ainda um terceiro encarregado de "pilotar" a outra pick-up. As equipes podiam chegar a contar com dezenas de integrantes, dependendo do tamanho e importância do negócio.

\begin{abstract}
A equipe nada mais é do que a reunião de duas, três ou mais pessoas (quase sempre rapazes), que armam uma aparelhagem de som, compõem uma discoteca (só de soul no caso dos bailes black, onde não se aceita outro tipo de música), armam um esquema de iluminação tipo boate, com spots verdes, vermelhos, amarelos, roxos, azuis acendendo e apagando, variando as composições e os efeitos segundo a criatividade de cada equipe. Nas equipes menores, todo esse aparato cênico é confeccionado no fundo de quintais do subúrbio, à base de madeira compensada e papel de balão. (FRIAS, 1976, p. 4)
\end{abstract}

Além da produção do baile em si, as equipes realizavam o transporte e a instalação de seus sistemas de som, que se tornavam cada vez maiores e mais potentes, e preparavam a iluminação e a decoração do salão. Segundo Essinger (2005, p. 27), o DJ Marcão, da equipe Cash Box, uma das maiores da época, fazia seus bailes com um equipamento especial, com caixas de som 
pequenas e potentes que facilitavam o transporte e transmitiam o som de um gravador e de fitas cassetes, dispensando a utilização de vinis. O pai e o tio, técnicos em eletrônica, montaram amplificadores com peças importadas, e Marcão foi o primeiro disc-jóquei a discotecar em um som estéreo (HUMBERTO DJ, 2011), chegando a montar inúmeros amplificadores através de kits importados. Os DJs eram responsáveis por escolher e tocar o set list do baile, mas também atuavam como animadores, realizando sorteios e concursos, criando diferentes climas para os diversos momentos do baile. Como mestres de cerimônia, muitos DJs ultrapassavam o papel de enterteiners e proferiam discursos inflamados e politizados em torno da conscientização racial. Em outras esquipes, os DJs faziam a animação, realizando sorteios de discos e ingressos, camisas, boinas e sapatos, premiações em dinheiro para melhores dançarinos e concursos de beleza. Havia premiações para melhores dançarinos e concursos de beleza específicos, que celebravam tanto uma estética afro-brasileira, quanto um estilo baseado em um visual inspirado em celebridades afro-americanas. Essas eram estratégias que buscavam uma conscientização racial a partir de uma valorização estética e uma celebração de um estilo visual, mas também performático, em detrimento de uma atuação político-pedagógica mais convencional.

A atmosfera das festas soul é sempre vertiginosa e feérica: lanternas estroboscópicas decompõem gestos e parecem eliminar a gravidade; projetores vermelhos varrem um mar de cabeleiras afro que se agitam compassadamente; uma grande esfera de espelhos facetados, suspensa no teto do galpão, espalha um faiscamento constante. (BLACK RIO, 1976, p. 154)

Cada vez mais profissionalizados, os donos de equipe eram os contratantes dos DJs, técnicos de som e dançarinos e detinham os direitos fonográficos de alguns dos sucessos que tocavam em seus bailes, posteriormente lançados em coletâneas em vinil. Apesar de muitos DJs serem famosos, a maioria ainda era funcionária das equipes: "O DJ tocava virado de costas para a plateia, para que todo mundo pudesse ver da pista de dança o equipamento piscando”. (VIANNA, 1988) Ou seja, a equipe era a estrela maior do baile. 
O DJ sempre foi importante no Black Rio, mas é verdade que sempre foi muito mal pago, explorado mesmo. Enquanto os donos das equipes enriqueciam, iam pagando miséria aos discotecários. E o mais chato era que o nome do DJ nunca aparecia muito. ${ }^{35}$ (ASSEF, 2003, p. 46)

Aos poucos, alguns DJs começaram a desenvolver performances diferentes, como os da Cash Box, que "se colocavam à frente do palco e da aparelhagem, tocando, dançando e animando o público, exibindo uniformes com a marca da equipe”. (ASSEF, 2003, p. 46) Por vezes, DJs montavam suas próprias equipes e faziam sucesso, chegando inclusive a apresentar programas de rádio e televisão. Monsieur Limá, discotecário e empresário de bailes, teve um programa de televisão aos sábados, inspirado no programa americano Soul Train, ${ }^{36}$ divulgando as novidades do soul e apresentando grupos de dançarinos.

Mr. Funky Santos também teve uma intensa atuação no mercado carioca da black music. Comandou programas em emissoras de rádio importantes, como Imprensa FM, Roquete Pinto, Tropical e Manchete FM. E com sua foto nas capas, lançou, até os anos 1980, uma série de cinco coletâneas em vinil dos hits de soul e funk que faziam sucesso em seus bailes. Na Top Tape, uma das mais importantes gravadoras cariocas nos anos 1970 e 1980, foi responsável pela produção de dezenas de álbuns de outras equipes de som, como Black Power e Cash Box. Santos se afastou da cena após seu filho ter sido assassinado na porta de um baile funk no Rio e passou a atuar como corretor de imóveis até vir a falecer com um câncer no estômago em 2012.

Ademir Lemos também investia na área de produção fonográfica, um negócio até mais lucrativo que os bailes. Restrições de importação limitavam severamente chegada ao mercado de discos brasileiro de selos norte-americanos independentes como Motown e Stax. Isso favorecia as multinacionais com afiliadas brasileiras, como a Columbia Broadcasting System (CBS) e a Philips, dona da Polygram. Essa vantagem permitia que as multinacionais,

35 Depoimento de Mr. Funky Santos.

36 Soul Train foi um musical televisivo diário americano fundamental para a história black music que começou a ser exibido em 1971 e durou até 2006, voltado para apresentação de shows e números de dança. 
ao lado de selos brasileiros regionais, adquirissem os direitos para distribuir singles americanos independentes no Brasil e também lançar coletâneas localmente. Lemos, assim, conseguiu negociar as marcas das mais importantes equipes de soul para as companhias de disco, que davam nome a coletâneas de sucesso, com as músicas mais tocadas nos seus bailes. E o público dos bailes de soul era um mercado garantido para esses álbuns, divulgados também por meio de estratégias de marketing preliminares, como concursos e sorteios. Assim, produziu o primeiro disco da equipe SGP, lançado pela Top Tape em 1974, que obteve grande êxito. Em meio a esse sucesso comercial, Lemos rapidamente adotou a retórica do soul, com o discurso menos militante do "negro é lindo", tradução de "Black is beautiful", lema estadunidense que não denominava uma organização específica, mas foi apropriado por diversos movimentos civis e negros e tinha relação com a propagação do amor próprio e da autoafirmação, exigindo respeito e difundindo a valorização de novos padrões estéticos de beleza negra, mas também se relacionava a noções de boa aparência, moralidade e bom comportamento. Outros DJs que conseguiram fazer sucesso para além de suas equipes foram Mister Paulão Black Power, Luizinho Disc-jóquei Soul e DJ Samuel, conquistando seguidores assíduos e deixando suas marcas na cena black carioca. ${ }^{37}$

Mesmo com essa popularidade inicial, ainda havia muita dificuldade para encontrar nas prateleiras das lojas os sucessos internacionais do soul. Esses LPs específicos eram extremamente raros e importados, e poucas lojas trabalhavam com esse segmento. Normalmente, um lançamento estrangeiro demorava de dois a três meses para chegar ao Brasil, quando chegavam, "[...] tanto que os discotecários cariocas continuavam a chamar aquela música soul, quando funk era a palavra usada nos EUA”. (VIANNA, 1987, p. 53) A solução encontrada por muitos DJs foi contar com encomendas feitas a amigos, comissários e aeromoças que viajavam para os EUA e tinham condições

37 "Houve um tempo em que o discotecário era uma figura apagada no jogo de luzes, som e alegria da pista de dança. Era o maestro sem batuta, escondido entre pilhas de discos, às vezes jogado num canto qualquer, atrás de pratos, copos e panelas, ao lado da copa ou do bar de uma boate. Agora o cenário é outro... De repente, aquele modesto canto passou a ficar pequeno demais para a importância dos DJs das mil e uma noites de som...". Mário Henrique Peixinho, programador da rádio Mundial, na contracapa do LP DJs 77. (RCA Victor, 1977, encarte de um disco). 
de trazer os últimos lançamentos (VIANNA, 1987, p. 53), especialmente "porque nas lojas, os profissionais de mais nome ou com melhores relacionamentos tinham prioridade nos lançamentos”, de acordo com Essinger (2005, p. 34). A oferta de novidades era escassa, especialmente porque o número de equipes foi aumentando, mas com a maior profissionalização e o aumento dos lucros, muitos DJs passaram também a viajar para os EUA a fim de adquirir novidades, indo especialmente para Nova York e Miami - às vezes, viajando e retornando no mesmo dia. No Brasil, os vinis custavam caro, tanto os vendidos nos balcões das lojas quanto os encontrados no câmbio negro: "um compacto importado e raro chegando a custar de Cr\$ 2 mil a Cr\$ 3 mil, os menos raros a Cr\$ 500, no mínimo”. (FRIAS, 1976, p. 4) Às equipes e aos disc-jóqueis com menor verba, restava a saída de realizar as "transações de discos” (VIANNA, 1987, p. 53), em que equipes e discotecários trocavam e vendiam discos entre si.

Os DJs tinham preferência pelos Disco Mix, que eram discos, a maioria de 12 polegadas (LP) [...], com várias versões de uma ou algumas músicas remixadas, de forma que ficassem levemente modificadas da versão original (algumas vezes apenas com sua duração alongada), o que conferia a marca da exclusividade àquele DJ e sua equipe de som que conseguiu tal raridade. Mas as raridades também poderiam vir por meio de compactos importados de 7 polegadas, que tocavam a velocidade de 45 rotações por minuto $(\mathrm{rpm})[\ldots]$, conhecidos como compactos de Funk Forty Five. (BRAGA, 2015, p. 62)

As equipes competiam para conseguir mais novidades e alguns DJs retiravam o rótulo do disco para evitar que possíveis concorrentes descobrissem os nomes dos artistas e das faixas, tornando-as "exclusivas" ou fazendo uso de recursos mais escusos, como trocar o nome de uma música de sucesso por outro título, ocultando o nome do artista ou disponibilizando informações falsas. (VIANNA, 1987, p. 53) Um dos donos da equipe Curtisom, Reginaldo, conta ainda que importadores de discos clandestinos muitas vezes traziam poucas cópias do mesmo vinil e as vendiam já sem capa e com selos adulterados. Se algum DJ ou dono de equipe quisesse ter uma determinada canção, deveria, pois, entrar em contato com o próprio comerciante que 
trazia as encomendas, pois apenas o vendedor detinha as informações sobre o nome da música e sobre o artista solicitado, mantendo-as em segredo. (GIRALDO, 2014, p. 26) O DJ Marlboro, um dos maiores expoentes da cena funk carioca, conta em depoimento a Pedro Schprejer:

A gente ia para o baile para escutar músicas que não ouvia em lugar nenhum. Algumas delas, quando tocavam, o público urrava. Não tinha internet, era muito difícil conseguir disco importado. Algumas músicas eram preciosidades. Vi um cara trocar um fusca por um compacto importado - não estou brincando. (SCHPREJER, 2009)

É neste momento que se consolida a importância do trabalho dos DJs e dos bailes como agentes e espaços de intermediação entre gêneros musicais e fãs e consumidores. Em muitos casos - e no universo da black music em geral-, o papel dos DJs tem extremo valor no processo de criação e consolidação dos gêneros, pois suas ações, historicamente, têm sido mais eficientes do que a de jornalistas e críticos, a partir da descoberta de novos mercados e da colocação em prática de novidades apreendidas nas experiências das pistas de dança. (FRITH, 1996, p. 88) Em uma era pré-internet, em que aparelhos de TV, vitrolas e discos ainda eram itens de "luxo" para uma população desfavorecida economicamente, o rádio e os bailes, através do trabalho de disc-jóqueis e produtores, funcionavam como "filtros", facilitando o acesso a uma cultura internacional. "Nos bailes era onde se ouviam as novidades. Ali, todos perceberam que o futuro poderia ser mais dançante". ${ }^{38}$ (ASSEF, 2003, p. 47) Como ainda não havia gravadoras promovendo fortemente esses nomes da black music no Brasil, o DJ assumia o papel de "garimpeiro", descobrindo novidades, raridades e se destacando perante seus pares. Muitos discotecários se tornavam famosos, inclusive, por serem os únicos a possuir um determinado disco, atraindo pessoas para seus bailes, pois era apenas neles em que se poderia ouvir uma música específica. (ASSEF, 2003, p. 26) Ao mesmo tempo, os DJs assumiam e propagavam ideais de carisma e juventude, e suas atividades eram associadas ao novo por serem retransmissoras e difusoras

38 Depoimento do DJ Corello publicado no livro Todo DJ já sambou: a história do disc-jóquei no Brasil, de Assef (2003). 
das novidades de uma cultura global, atualizando suas ações mediadoras e atores políticos. A demonstração de suas capacidades de atração e prestígio garantia uma visibilidade e um certo poder de condução das massas, a partir da atribuição para si de um possível caráter “divino” de líder, que remeteria a um tipo ideal de autoridade ideológica (BARRETO, 2007), o que era realçado pela exibição de imagens, discursos e valores compartilhados nos bailes.

Bairros da Zona Norte - como Colégio, Irajá, Marechal Hermes, Rocha Miranda, Nilópolis, Acari, Andaraí, Bangu, Catumbi, Coelho da Rocha, Duque de Caxias, Grajaú, Leopoldina, Madureira, Méier, Mesquita, Nilópolis, Parada de Lucas, Pavuna, Penha, Ramos, Tijuca, Vila da Penha e Vilar dos Telles e Pavuna - passaram a compor uma cena musical pautada pela black music, que se estendeu até a Zona Oeste, mais distante do centro da cidade. A economia do Rio de Janeiro se baseava em uma forte estrutura terciária, o que incentivava a priorização de investimentos urbanísticos pela administração pública. (MOTTA, 2000, p. 85) Muitos centros comerciais populares e "calçadões” foram construídos e se converteram em áreas de intenso trânsito de pessoas. Importantes polos comerciais e urbanos do subúrbio, como Madureira, Caxias, na Praça do Relógio, ${ }^{39}$ Vilar do Teles ou na Rua Sete de Setembro, no Centro do Rio (FRIAS, 1976, p. 3), se tornaram pontos de encontro e de decisão dos blacks e locais preferenciais de divulgação dos bailes por meio de cartazes, faixas pintadas à mão, ${ }^{40}$ colocadas em avenidas de intenso movimento e distribuição de panfletos. "Depois alguns muros da cidade passaram a funcionar como quadros de aviso, agora menos usados porque baixou a fiscalização multando as equipes anunciadas”. (FRIAS, 1976, p. 4)

39 O DJ Paulinho, da equipe Black Power, se lembra dessas movimentações: “sempre todos os sábados, reunião dos Black's para discutir sobre músicas, discotecários, equipes que melhor se apresentavam etc... Detalhe: Essas reuniões rolavam e os participantes sempre se vestiam no maior estilo Black, usando chapéu, óculos escuros, bengalas, blazer, sapatos com dois e três andares. A Praça de Duque de Caxias ficava repleta de gente e parecia até que você estava no Harlem!?”. Disponível em: <http://zinezerozero.blogspot.com.br/2011/03/bgirlz-2011.html>. Acesso em: 6 abr. 2016.

40 A urbanização promovida por Chagas Freitas, governador do estado da Guanabara (1971-1975) e do Rio de Janeiro (1979-1983), levou à criação de grandes espaços chamados calçadões ou ruas de pedestres, às quais era vedado o trânsito. Os calçadões eram exclusivamente voltados para o comércio, mas com espaço para canteiros, árvores, bancos de praça, favorecendo a circulação de pessoas, como um shopping a céu aberto. 
Silva (2013, p. 139) lembra que os flyers fizeram parte da cultura da música negra norte-americana, especialmente no universo hip hop, relembrando que as filipetas foram criadas no século XII, mas foram popularizadas com o advento da fotocópia, já nos anos 1960, o que barateou a reprodução de panfletos, facilitando a sua produção em qualquer espaço e em maior escala. No Brasil, as primeiras filipetas de divulgação dos bailes soul eram simples, datilografadas e recortadas à mão. À medida que os bailes cresciam, as equipes criavam panfletos mais elaborados, utilizando cores, slogans criativos, designs mais modernos e diferentes elementos gráficos que chamavam a atenção dos frequentadores e reproduziam marcas estéticas da época, transformando os panfletos em uma espécie de documento da história da cena black. Os também chamados volantes eram distribuídos duas ou três semanas antes dos bailes e anunciavam as atrações das noites, as equipes e artistas participantes, os concursos e premiações e ainda davam informações sobre as conduções que poderiam ser utilizadas para se chegar ao local do baile. Não era raro um volante anunciar mais de uma festa, em que diferentes equipes dividiam os custos de produção, impressão e distribuição dos panfletos. Frias (1976, p. 4) transcreve o texto de um dos volantes coletados:

Grêmio de Rocha Miranda, Av. dos Italianos, 282 apresenta a maior festa da cidade. O $3^{\circ}$. Aniversário da Horus. Dia 17 de junho, Sábado, 19 horas. Horus, o aniversariante somos nós e o presenteado é você. Conduções: 960 - Penha - N. Iguaçu - B. Roxo - Méier - V. Nova - Cascadura - Jardim Botânico - Cascadura - Vilar dos Teles. Com este entrada grátis. Ou Vitória T. C. Rua Porto Alegre. Hulk apresenta Os Gigantes do soul Messiê Limá. Filme de Wattstax. Santos. E dançando a vedete Cia Soul. Atenção: Hulk oferece ao melhor dançarino Cr\$ 500,00.

Ou ainda: "Atenção: William Hulk oferece um sapatão ao melhor dançarino”. Mensagens positivas de paz e incentivo também eram transmitidas pelos panfletos e convites, como "o bom andamento do baile depende exclusivamente de você” (BLACK RIO..., 1978, p. 154), demonstrando um desejo dos organizadores de garantir a paz e a ordem em suas festas. 
A expansão do público do soul na segunda metade dos anos 1970 possibilitou aos produtores dos bailes o aluguel de grandes espaços, como clubes maiores e quadras de escolas de samba. Segundo Frias, na escola Império Serrano, por exemplo, os bailes já estavam praticamente incorporados ao calendário de eventos da agremiação. ${ }^{41}$ Os clubes e escolas podiam ficar com $20 \%$ a $50 \%$ da bilheteria arrecadada, e muitos firmavam contratos com as equipes, garantindo a realização semanal de bailes. "A Black Power tem Contrato com o Boêmios de Irajá, para onde carrega, no mínimo, 3 mil pessoas cada sábado. A Soul Grand Prix com o Maxwell, cuja lotação se completa a cada domingo". (FRIAS, 1976, p. 5)

Com o aumento da lucratividade, foi possível às equipes o pagamento de anúncios em rádios populares, como a Mundial, e em jornais, como os tijolinhos do Jornal do Brasil. "Big Boy e a Rádio Mundial também sempre foram divulgadores dos bailes soul, cada chamada custando, hoje em dia, nunca menos de Cr\$ 300 ou Cr\$ 500. E cada equipe usando de cinco a dez chamadas por dia” (FRIAS, 1976, p. 5), o que não substituía a divulgação barata por meio do anúncio dos próximos bailes realizados pelos próprios discotecários no final de cada noite. Com o aumento do lucro, as equipes podiam comprar espaço nos jornais para divulgar os bailes. As equipes diversificavam suas atividades, e até bailes infantis de soul eram realizados.

Em meados da década, começaram a ser organizados os festivais de equipes. Assim, em um dia, sete equipes podiam tocar em um mesmo baile. $\mathrm{O}$ Primeiro Encontro dos Blacks da Guanabara foi realizado no Greip da Penha em 1977 e reuniu quase 15 mil pessoas em um lugar onde só cabiam, no máximo, 5 mil. O evento, realizado pela SGP e pela equipe Black Power, contou ainda com o show da banda Watergate Tape, formada por músicos americanos que moravam no Rio. Esses festivais, geralmente, começavam no final da tarde e iam até a madrugada do dia seguinte, com várias equipes se sucedendo ao longo do evento. Cada equipe ocupava um lugar no salão para montar

41 Para Hanchard (2001, p. 140), a escolha das quadras de escolas de samba para a realização de bailes cada vez maiores era devido ao alto valor do aluguel de salões sociais, bem como à "relutância de muitos proprietários brancos em permitir que grandes levas de brasileiros negros entrassem em seus prédios". 
as caixas de som. Na sucessão das apresentações, enquanto uma equipe tocava, as outras aguardavam sua vez, em silêncio e com as luzes apagadas. Os fãs de cada equipe iam se reunindo proximamente às equipes de preferência, dividindo a pista em territórios.

Outro evento grandioso foi o lançamento do disco da SGP ${ }^{42}$ em 1976, no Guadalupe Country Clube, que contou também com aproximadamente 15 mil pessoas. "A piscina do clube estava vazia e as pessoas dançavam dentro dela. A passarela em frente ao Guadalupe estava tomada", narra o Nirto, um dos donos da SGP, para Essinger (2005, p. 29). Não só a piscina e a passarela, mas a multidão fechava a própria Avenida Brasil. Contudo, o baile teve que ser interrompido mais cedo, por conta da presença da Polícia Militar (PM), que enviou para o local mais de 600 homens da tropa de choque da aeronáutica, segundo Dom Filó em depoimento a Essinger (2005, p. 29). Um massacre eminente foi evitado pelo DJ, que solicitou que acendessem as luzes do salão, desligou a música e acalmou o público, terminando o baile:

Peguei o microfone e agradeci a presença do coronel, dizendo que ele estava ali para garantir a ordem. Foi tudo o que pude fazer. Ele falou que eu tinha resolvido um problemão e que a ordem era baixar o cacete. Puseram um campus em mim e fui levado para interrogatório. (DOM FILÓ, 2000, p. 1)

A polícia acompanhava de perto a movimentação dos bailes, e, em muitos registros da época, é possível encontrar informações preciosas sobre os fatos. Em relação ao baile do Guadalupe, o pedido de reforço policial foi feito pela direção do clube. Mas não por temor de atos de violência, e sim por conta do receio em relação ao excesso de lotação. Nos registros, havia ainda referências a uma possível proibição de que a SGP tocasse no Grêmio Recreativo

42 "The Beautiful Black People estaria no maior sufoco, não fosse o surgimento das equipes de som. There was a time em que foi um só Baile da Pesada. Hoje desdobraram-se em centenas de Disco Dance instalados nas festivas domingueiras de clubes. A Equipe Soul Grand Prix conquistou, através de suas multimilionárias performances, o direito de registrar esse acontecimento tão marcante". (Texto de encarte do LP da SGP escrito por Ademir Lemos, produtor do disco, Top Tape, 1976) 
de Rocha Miranda, pois a equipe já vinha sendo investigada pelo Departamento da Ordem Política e Social (Dops) por prática e incentivo de discriminação racial, segundo consta no pedido de busca do Departamento Geral de Investigações Especiais (DGIE) emitido pela Secretaria Geral do Conselho de Segurança Nacional, $n^{\circ}$ 02343, de 2 de julho de 1976, de acordo com Pires (2015, p. 42).

Os relatórios da polícia da ditadura, de fato, observavam um clima de tranquilidade nos bailes, e as investigações se referiam mais às tentativas de descobrir possíveis organizações radicais de fundo racial. Mesmo assim, era comum haver repressão a vários bailes, em que discos eram apreendidos e DJs eram levados para depor, como ocorreu festa de lançamento do primeiro disco de Gerson King Combo, em 1976, no Olaria Sport Club, que havia reunido 30 mil pessoas. Muitos disc-jóqueis, evitando perder valiosos discos importados de soul, colocavam-nos em meio a vários discos de samba, que eram entregues à polícia na hora das batidas e apreensões. Eventualmente, até o som da discotecagem era substituído quando havia notícias de que a PM estaria chegando, e o soul era substituído por discos de samba, modificando a trilha sonora dos bailes para eliminar suspeitas e evitar a violência policial. Depois que a polícia ia embora, o soul voltava a tocar.

Frias (1976, p. 4) reproduziu a indignação de um entrevistado: "por que é que preto não pode fazer festa que baixa logo os cana?”. Durante a Terceira Caravana Soul, realizada em junho de 1976 na quadra da escola de samba Império Serrano, em Madureira, foi exibido pela primeira vez o documentário Wattstax no Brasil. Durante o festival, policiais infiltrados entre os participantes do baile relataram detalhes da exibição, que não sofreu nenhuma forma de repressão por parte da polícia. E, segundo o relatório policial consultado por Alberto (2009, p. 15), o filme não foi exibido na íntegra, e apenas algumas cenas foram mostradas, sem áudio. Para o serviço secreto da polícia, isso não representou maiores problemas políticos, já que, sem o áudio, possíveis discursos "demagógicos" subversivos não seriam transmitidos para o público, desconsiderando qualquer perigo na exibição apenas das imagens em movimento. Alberto (2009) lembra que, naquele tempo, a censura do governo militar havia proibido a exibição de filmes nos cinemas, 
particularmente americanos, que tivessem uma temática explicitamente racial, a fim de evitar que os negros brasileiros fossem influenciados pelos movimentos afro-americanos.

O fato de a polícia secreta descartar o potencial político de Wattstax em razão da ausência de som sugere suas habilidades limitadas, naquele momento das investigações, para perceber o poder das imagens visuais para inspirar e comunicar novos tipos de identidades raciais e políticas. Wattstax - com suas cenas vibrantes de quase cem mil negros americanos ostentando cabelos afros, dashikis e diferentes estilos soul e funk, e enchendo o LA Coliseum em um evento voltado majoritariamente para a comunidade negra, durante o qual Jesse Jackson conduziu o público (com os punhos erguidos) em uma excitante versão de seu poema 'Eu sou alguém' (e suas palavras piscando por todo o estádio), e o National Black Anthem - comunica uma afirmação da negritude e orgulho racial para os quais nenhuma trilha sonora ou discurso político teria sido necessário. (ALBERTO, 2009, p. 15)

Já com o som, o filme pareceu ter um efeito mais intenso. Em julho de 1976, o recém-criado IPCN resolveu realizar, em comemoração ao primeiro aniversário da organização, uma exibição com áudio de Wattstax. Mas não em nenhum clube suburbano ou durante algum baile. O local escolhido foi o Museu de Arte Moderna (MAM) do Rio de Janeiro, no bairro do Flamengo, Zona Sul da cidade, uma instituição de prestígio para a elite e também para os movimentos contraculturais da época. Esse ato concedeu uma importância simbólica ao evento, organizado por uma militância negra e voltado para uma audiência também negra em um espaço percebido como branco e ocupado por uma elite intelectual. Lena Frias (1976) descreve o episódio como um momento de comoção pública, em que alguns indivíduos da plateia seguiam as frases de Jesse Jackson com os pulsos levantados, emocionados. Sobre a dimensão de Wattstax e sua importância para o movimento black, a jornalista comenta que o filme funcionava uma "espécie de modelo e, como tal, exaustivamente visto e estudado": "Passou a constituir-se num sensibilizador permanente, atuante e eficaz. As frases de Wattstax são decoradas, 
repetidas, bordadas nas roupas, cantadas, cantaroladas, dançadas, assoviadas”. (FRIAS, 1976, p. 4)

\begin{abstract}
Aberta a bilheteria, rapidamente os 220 lugares ficam ocupados e, poucos minutos após, quase 320 pessoas comprimem-se na sala da Cinemateca. Lá embaixo, no pátio outros tantos tentam entrar. [...] O público negro (havia dois brancos presentes, os habitués do museu ficaram lá embaixo), não presta muita atenção às palavras, mas passa a gritar e aplaudir logo que começa a projeção [...]. O público repete as palavras, as frases, embora o sentido lhes possa até ser desconhecido. E quando o Reverendo Jesse Jackson aparece na tela conclamando os negros americanos à profissão de fé na própria raça, no cinema, a exemplo do que sempre acontece em todas as exibições de Wattstax em todo o Grande Rio, repete com eles as palavras que fazem chorar um jovem negro de 16 anos, Roberto, estafeta, que está ao meu lado, espremido no corredor da cinemateca 'I am somebody'. Jessie Jackson fala na tela, com o punho erguido braço dobrado para dentro, a multidão no estádio de Los Angeles repete gesto e palavras. Na pequena multidão reunida no MAM, como nas grandes multidões reunidas nos ginásios da Zona Norte e Baixada, alguns punhos também repetem o movimento, e todo mundo dizia em coro, uns mais altos outros quase sussurrando: 'I am somebody'. ${ }^{43}$ (FRIAS, 1976, p. 4)
\end{abstract}

O soul chegava de vez à Zona Sul e, em 1976, foi organizada a primeira festa soul por uma equipe de som do subúrbio no Clube Mourisco, em Botafogo. O baile realizado em 31 de julho, sábado, foi divulgado em volantes que exibiam o título "Soul invade a Zona Sul” e contou com a presença de 9 mil pessoas, segundo cobertura do Jornal do Brasil. (O SOUL..., 1976, p. 5) O público dançou de oito da noite às cinco da manhã, animado pela SGP, promotora do evento, e pela equipe Black Power, além da animação do discotecário Monsieur Limá, que lançava sua equipe de som, a Soul Discotheque,

43 Wattstax também foi exibido na sede da Associação Brasileira de Imprensa (ABI) em 6 de setembro de 1977, em um seminário intitulado "O soul - e suas implicações sócio-econômicas e culturais na comunidade", com a participação do crítico musical Roberto Moura e da militante negra e antropóloga Lélia Gonzales. 
que, como o nome apontava, era especializada em música disco e passou a disputar com as equipes de soul a preferência do público. O próprio Monsieur Limá passou, posteriormente, a contratar equipes de soul e a produzir bailes na Zona Sul, ganhando muito dinheiro. (HANCHARD, 2001, p. 140) O baile do Mourisco serviu como marco da onda soul pela cidade, atingindo diferentes grupos sociais.

Apesar de representarem uma importante plataforma de divulgação de artistas nacionais, era majoritariamente a música norte-americana que abastecia os bailes. O inglês não era dominado pela grande maioria dos fãs e participantes da cena, mas isso não impedia o consumo dessas canções, já que o gosto pelo ritmo, a sonoridade e a pulsação do soul ultrapassavam fronteiras idiomáticas. E o consumo de produtos americanos também acentuava um desejo e uma demanda por ingressar em uma modernidade idealizada por parte desses jovens, que não mais se identificavam com produtos culturais tradicionais, como o samba e outros gêneros populares brasileiros. Foi naquela época que surgiram as primeiras "melôs", como adaptações de expressões em português, divertidas, que se assemelhavam e aproximavam à pronúncia de fraseados em inglês. "Então o sujeito ouvia 'Hard Work', do John Handy, e saía cantando 'Morre o Boi'. Dali a cinco minutos, tinha 2 mil pessoas no baile cantando 'Morre o Boi”', lembra o produtor de rap Fábio Macari em depoimento a Assef (2003, p. 26).

Um grande chamariz para o público e uma forma eficaz de manter o entusiasmo ao longo dos bailes - que tinham, em média, duração de seis horas - foi a incorporação de performances ao vivo, e as equipes passaram a organizar grandes shows, que deram um especial incentivo aos cantores de soul brasileiro. Tim Maia, Jorge Ben Jor, Cassiano, Gerson King Combo, Tony Tornado compunham um panteão para o soul brasileiro diante de uma audiência massiva. O primeiro disco de King Combo (Gerson King Combo, Polydor, 1977), inclusive, foi lançado em um grande baile no Portelão, em Madureira, durante um encontro das equipes de soul Black Power, SGP e Uma Mente Numa Boa, em 1977. A preocupação com a questão racial não era uma unanimidade, mas alguns DJs ganharam fama justamente por articular lazer e política de forma inovadora. No Rio, as equipes se diferenciavam por suas ações e estratégias específicas, denotando diferentes motivações. 
Muitos DJs buscavam apenas entreter suas audiências, animando seus bailes ao som do soul, em oposição àqueles que levantavam a bandeira do orgulho negro mais seriamente.

Os bailes - que, a princípio, eram uma opção mais barata e acessível para populações de menor renda - passaram a aumentar o valor da entrada, diante do aumento dos custos para produção, compra de equipamentos, pagamento de funcionários e aluguel de espaços maiores, inclusive em clubes mais elitizados, como o Tijuca Tênis Clube ou clubes na Zona Sul. Em Cavalcanti (1981, p. 8), um entrevistado que costumava frequentar as festas black na época declarou: "Coisa de louco, pagar cem cruzeiros num baile de 'soul', porque ele é coisa nossa e os donos das equipes que organizam os bailes estão ficando ricos à nossa custa”. Há um conflito de valores, pois, de acordo com informação de Bahiana (2006, p. 304), os valores praticados para a entrada nos bailes giravam em torno de cinco a oito cruzeiros. Era comum que mulheres não pagassem a entrada, mesmo que os ingressos tivessem valor acessível. Também segundo Frias (1976), as entradas poderiam custar entre sete e oito cruzeiros, e a Veja (BLACK RIO, 1978, p. 154) contabilizou ingressos que oscilavam “entre 8 e 25 cruzeiros (damas grátis)". Independente do valor da entrada, o fato é que os bailes reuniam multidões, e os donos das equipes faturavam alto, o que era motivo de crítica, pois apontava para uma suposta falta de comprometimento com a população negra e suburbana e com demandas específicas desse grupo, como opina um jovem negro frequentador dos bailes: "Vários promotores de baile enriquecem em cima de nós [sic] para depois irem gastar em 'discotheque' de brancos”. (CAVALCANTI, 1981, p. 8-9) E Bahiana (2006, p. 304) acrescenta: "Um fim de semana rendia, em média, Cr\$ 200 mil para essas equipes nas quais, via de regra, os discotecários - senhores supremos do repertório - eram brancos".

A imprensa carioca, percebendo o efervescente movimento que mobilizava milhares pessoas, batizou o fenômeno de Black Rio. A proliferação desses bailes black chegou a outras cidades do Brasil, como São Paulo, Salvador, Belo Horizonte, representando uma criação conjunta de símbolos étnicos e partilhas de experiências socioculturais. Segundo Bahiana (2006), na época, as festas no subúrbio e na Zona Sul foram responsáveis pelo enorme índice de venda de discos de black music, superando, inclusive, o rock dos Rolling 
Stones ou do Led Zeppelin. ${ }^{44}$ Os frequentadores dessas festas eram vistos como um enorme mercado em potencial. Inicialmente, foram lançadas coletâneas com os principais sucessos dos bailes. Muitas delas eram assinadas pelas equipes de som e pelos DJs de maior prestígio, em pequenas gravadoras. A gravadora repassava uma parte das vendagens para as equipes, que se tornaram cada vez maiores e mais rentáveis. As majors do disco, estações de rádio e emissoras de TV ficaram ansiosas para lucrar com o potencial comercial do movimento Black Rio e tentaram garantir um lugar para o segmento da soul music no mercado musical nacional.

Como consequência dessa circulação, pode-se dizer que houve uma institucionalização do soul como um segmento estável dentro do mercado musical brasileiro até aquele momento. Não só pela atividade dos próprios artistas que atuavam no interior do gênero musical, como também pelos que praticavam mesclas com outros gêneros, propondo, inclusive, novas reconfigurações para o próprio samba, matriz musical nacional. Apesar de estratégias mercadológicas diferenciadas, o mercado fonográfico, junto a artistas e produtores, tentava articular uma forma de introduzir no Brasil a produção musical negra de sucesso produzida nos EUA, ao mesmo tempo em que se voltava para o incentivo da produção de músicos locais do gênero. Era uma maneira de explorar um mercado paralelo que se desenvolvia a partir da cena musical dos bailes black e de incorporar, na produção musical brasileira, matrizes e dicções internacionais, notadamente norte-americanas, que tinham a ver, necessariamente, com novas formas de comunicação e expressão, representando também estilos de vida e estratégias de sobrevivência e negociação simbólica.

44 De fato, apesar da importância no cenário mundial e de influenciar a música popular brasileira profundamente, o rock, durante os anos 1970 no Brasil, não alcançava grandes índices de vendagem, "com um consumo numericamente baixo (os grande vendedores estrangeiros do gênero, como as grupos Rolling Stones e Led Zeppelin, atingiram, no Brasil, marcas medíocres de vendagem, entre as 10 e as 30 mil cópias, no máximo, com uma saída média, mensal, entre 2 e 5 mil unidades vendidas)". (BAHIANA, 1980, p. 41) 


\section{A indústria fonográfica no Brasil dos anos 1970}

A década de 1970 pode ser considerada como um período de grande crescimento do mercado fonográfico brasileiro, que foi acompanhado pela reestruturação desse setor produtivo por conta de grandes investimentos de capitais nacionais e estrangeiros, que acompanhavam o rápido desenvolvimento das tecnologias de gravação e produção e a utilização de novos modelos de gerenciamento no interior das gravadoras. (MORELLI, 2009, p. 15) Os anos 1970 também podem ser definidos pela consolidação do mercado de bens culturais, ainda que sob a tutela de uma ditadura militar de cunho conservador e autoritário, que dava contornos a um projeto de "integração nacional" mediado pelo capital privado, gerando uma enorme expansão na produção, distribuição e no consumo da cultura. Desse modo, a integração da nação se dava por meio do consumo de bens culturais, interligando consumidores e cidadãos na construção de uma cultura em que o popular se confundia com o massivo e com o mercado.

Era um momento de expansão econômica que motivou, especialmente de 1965 a 1972, o crescimento de $400 \%$ do mercado nacional de discos (MORELLI, 2009, p. 87), cenário refletido diretamente em números: de 5,5 milhões de discos em 1966, passaram a ser vendidos 52,6 milhões em 1979. (VICENTE, 2008, p. 105) E de 1978 para 1979, o Brasil se tornou o sexto maior consumidor de discos do mundo (MORELLI, 2009, p. 96), colocando o país em uma posição bastante estratégica como um alvo importante dentro do mercado mundial. Diversas as filiais internacionais ampliaram suas atividades no país nesse momento:

- a Philips/Phonogram - depois PolyGram e, atualmente, parte da Universal Music - chegou ao Brasil a partir da aquisição da Companhia Brasileira do Disco (CBD) em 1960;

- a CBS - hoje, Sony Music-, já em atividade no Brasil desde 1953, garantiu boa fatia do mercado com o sucesso da Jovem Guarda;

- a Electric and Musical Industries Ltd (EMI), que chegou ao Brasil em 1969 por meio da aquisição da Odeon;

- a Warner, cuja subsidiária brasileira chegou aqui em 1976; 
- a Ariola, que integrava o conglomerado alemão Bertellsman (BMG) e chegou ao Brasil em 1979;

- a Radio Corporation of America (RCA), que operava aqui desde os anos 1920 e, mais tarde, também foi comprada pela Bertellsman, tornou-se o núcleo da BMG.

Além das internacionais, havia gravadoras menores nacionais, como a Copacabana, Continental, RGE-Fermata, Top Tape e Tapecar. Em 1971, surgiu a Som Livre, braço fonográfico da Rede Globo, criada para lançar LPs de trilhas de novelas. Outras gravadoras vinculadas a emissoras de TV também foram criadas, como a GTA (Tupi), Bandeirantes Discos (Bandeirantes) e Seta (Record). É nesse momento em que a estrutura organizacional da indústria fonográfica brasileira se complexifica a partir de uma progressiva especialização. E ganha cada vez mais destaque e importância o papel do produtor artístico na produção fonográfica, cuja visão estratégica possibilitava a criação de produtos altamente vendáveis. A produção musical como categoria profissional se desenvolveu na década de 1950, nos EUA, quando o produtor passou de responsável pela direção e supervisão das sessões de gravação para uma espécie de mentor criativo, envolvido diretamente na concepção de um disco. (SHUKER, 1999, p. 219) Inclusive, muitos produtores de renome começaram a pressionar as gravadoras para receber não só os créditos nas gravações, como também direitos autorais sobre as canções vendidas. De fato, com o desenvolvimento das técnicas de gravação, como a tecnologia dos múltiplos canais e do som estereofônico, o produtor podia ser reconhecido como coautor e também como um intermediário cultural que pesquisava e captava tendências, descobrindo novas possibilidades e aprofundando a qualidade do trabalho de criação e gravação. Além do produtor, havia uma crescente verticalização e hierarquização na estruturação dos departamentos e setores das gravadoras multinacionais. ${ }^{45}$

45 Tal situação indicava uma estrutura bem mais complexa de profissionais distribuídos em diferentes áreas: artística (equipe de produção, composta por orquestradores, regentes e produtores); técnica (especialistas em áudio e eletrônica); comercial (marketing, capa/embalagem, produção, distribuição e promoção dos discos); e industrial (matrizes). (CERQUEIRA, 2015, p. 6) 
Ainda segundo Cerqueira (2015), a Phonogram, por exemplo, que contava com um contingente de 170 empregados e 150 artistas em 1968, passou a ter, em 1974, 500 funcionários para atender apenas a 28 artistas. Isso era um reflexo direto do crescimento da indústria do disco brasileira e da modernização do setor, que crescia $15 \%$ ao ano em média - mesmo diante de dois momentos de falta de matéria-prima, por ocasião das crises internacionais do petróleo na época -, seguindo a ampliação do mercado de bens de consumo, com destaque especial para a venda de aparelhos de reprodução sonora. (MORELLI, 2009, p. 61) O mercado brasileiro apresentava, assim, um grande potencial, e outras majors se estabeleceram no país, interessadas em comercializar aqui sucessos internacionais.

A repressão e a censura também dificultavam a expansão do mercado de música popular brasileira, o que facilitava e incentivava ainda mais o lançamento, por parte das multinacionais, de sucessos estrangeiros, que passaram a predominar nas programações das emissoras de rádio e nos suplementos das gravadoras. (MORELLI, 2009, p. 62) Essa condição aumentava muito os lucros, visto que era muito mais barato lançar aqui um disco já gravado no exterior do que gravar um LP com artistas brasileiros. Além disso, os discos estrangeiros já tinham seus custos de gravação cobertos pelas vendas realizadas em seus mercados de origem. Ainda segundo Morelli (2009, p. 62), havia outra vantagem para as filiais instaladas no Brasil, que, apesar dos altos impostos sbre importação de gravações, as faziam entrar no país como “amostras sem valor comercial”, prática proibida por lei, mas tolerada pelas autoridades.

Em Morelli (2009, p. 63), é possível ainda encontrar alguns índices que demonstram a ocupação massiva do mercado brasileiro pela música estrangeira, notadamente a norte-americana. Levantamentos semestrais realizados pelo Jornal do Brasil no primeiro semestre de 1971 apontam que a música nacional ocupava 57,5\% do chamado "mercado de sucesso", mas logo no semestre seguinte ocupou apenas $37 \%$ desse mesmo mercado, caindo para apenas $16 \%$ no primeiro semestre de 1972 , com uma pequena recuperação no segundo semestre daquele ano, atingindo 17,5 pontos percentuais.

No começo dos anos 1970, 47\% de todos os discos fabricados no Brasil apresentavam artistas estrangeiros ou versões de músicas estrangeiras, de 
acordo com Dunn (2009, p. 191). Na intenção de tentar participar desse segmento, muitos eram os artistas que gravavam versões em português de sucessos internacionais ou cantavam em inglês. Vários cantores e bandas da época, inclusive, se apresentavam com nomes estrangeiros. Assim, uma boa parte dos artistas internacionais que faziam sucesso no Brasil, ironicamente, eram brasileiros. Como exemplo, havia Terry Winter, Michael Sullivan, Mark Davis (Fábio Jr.), Morris Albert, Christian, Demis Rousseau, Dave MacLean, Dee D. Jackson e bandas como a Light Reflections e Lee Jackson. O inglês se consolidava como o idioma do futuro, do consumo, e essa estratégia era utilizada como forma de conquistar um público brasileiro mais interessado em sonoridades importadas, sugerindo que "a adoção da língua inglesa e da postura internacional por parte dos artistas configurava-se como uma opção estratégica passível de conferir a seus trabalhos uma maior legitimidade junto aos jovens consumidores urbanos”. (VICENTE, 2009, p. 5) De certa forma, na década de 1970, pode-se perceber o encerramento de um processo cultural começado 50 anos antes de busca de uma identidade nacional brasileira, especialmente quando se observa como a esfera musical popular equacionou impasses, tensões e polêmicas criados ao longo do período. (NAPOLITANO, 2002a, p. 75) Esse momento correspondia a uma revisão de tradições anteriores e da própria memória musical, em que a música e o mercado passaram a absorver ou aderir aos modelos da música pop, abrindo-se esteticamente para novas formas e novos produtos.

\section{O segmento do soul}

A grande quantidade de lançamentos, sejam estrangeiros ou nacionais, não deixava dúvidas a respeito do crescimento acelerado do mercado consumidor brasileiro de discos nos anos 1970, que incorporava novos segmentos da população com um crescente poder de compra. Mesmo assim, apesar do empenho da indústria fonográfica para aproveitar o mercado brasileiro na venda massiva de rock internacional, bandas mais famosas, como Led Zeppelin e Deep Purple, aqui não obtiveram vendas expressivas. O mercado nacional tinha características peculiares e precisava ser explorado de maneiras diferentes. 
A música negra norte-americana já era razoavelmente consumida nos subúrbios do Rio, primeiro por meio do rock'n'roll de cantores como Chuck Berry e Little Richards, cujas carreiras foram ofuscadas por Elvis Presley. No Rio de Janeiro, a Jovem Guarda e os Beatles ocuparam a faixa musical destinada aos jovens nos anos 1960, além de conjuntos de baile, como Golden Boys (influenciados pelo doo-wop), The Fevers, Renato e seus Blue Caps. Cantores negros de "balanço" (ou samba-rock, samba-soul) também eram bastante requisitados, como Jorge Ben (antes de ser Ben Jor), Bebeto e Wilson Simonal, que faziam sucesso nos clubes do subúrbio e começavam a introduzir em suas canções sonoridades do soul. As primeiras gravadoras que se interessaram pela proposta foram a Top Tape e Tapecar, de porte mais modesto, que criaram eficientes estratégias de negócio ao contratar as duas equipes mais famosas, a SGP e a Dynamic Soul, para o lançamento de coletâneas com o repertório dos bailes de soul.

Outra equipe, a Sorac, também assinou contrato com a Top Tape, que investia no segmento e, apenas em um mês, em maio de 1976, lançou seis discos de soul, enquanto a Love Som fechou com a Phonogram. De acordo com Frias, os discos eram lançados com tiragens entre 10 e 20 mil cópias, que vendiam com facilidade, especialmente entre o público da Zona Norte: "Propositadamente, tiram-se poucas cópias, o que garante a raridade do disco e a possibilidade de relançamento posterior a preço bem mais alto. Ou a vendagem no câmbio negro, a preço que dependerá da qualidade da seleção musical”. (FRIAS, 1976, p. 4) Em seguida, a SGP foi contratada pela Warner, Elektra e Atlantic (WEA), recém-chegada ao Brasil e interessada em atingir um mercado jovem mais amplo. Na segunda metade da década de 1970, a Warner Music, fundada em 1954, conseguiu rapidamente ultrapassar a CBS, a RCA e a Capitol e tornou-se a maior gravadora e, por conseguinte, o maior conglomerado de entretenimento do mundo, garantindo uma participação de $25 \%$ no mercado norte-americano. (MIDANI, 2009, p. 98) Desde 1960, o espetacular crescimento do mercado mundial da indústria fonográfica havia chamado a atenção dos grandes conglomerados da comunicação, que compraram todas as companhias independentes de discos que existiam no mundo.

Em junho de 1976, a Warner abriu uma filial no Brasil e se dedicou a vender seu catálogo norte-americano no país, reproduzindo matrizes 
estrangeiras para atender a uma demanda crescente de consumidores mais jovens no mercado brasileiro, conquistando uma boa fatia do mercado nacional. Nos anos seguintes, passou a lançar números reduzidos de discos de artistas brasileiros de seu catálogo enxuto de contratados, o que garantiu uma ampliação de sua participação no mercado local, conquistando um público fiel e uma maior margem de lucros ao longo do tempo - a "faixa de prestígio”. Era a reprodução da mesma estratégia adotada por André Midani na Philips nos anos 1960. Com pouca rentabilidade, a Philips tornou-se sinônimo de MPB quando Midani, então principal executivo da gravadora, decidiu cortar vários artistas do seu cast, mantendo apenas 50 de 150 cantores. (ALONSO, 2011, p. 330) Em comum, os que restaram mantinham o foco na juventude urbana brasileira da época, como Caetano Veloso, Elis Regina, Jorge Ben, Gal e Chico Buarque, entre outros. Essa mesma estratégia de buscar um público jovem, mantendo um cast reduzido de artistas e explorando o catálogo internacional da gravadora, foi mantida por Midani, quando saiu da Philips-Phonogram para fundar a WEA no Brasil, ${ }^{46}$ se tornando um dos nomes mais importantes da indústria fonográfica do país. Além de conservar artistas da MPB que tinham surgido a partir do Tropicalismo (MORELLI, 2009, p. 101), investiu também no emergente segmento do soul brasileiro, como forma de aproveitar o sucesso do gênero no contexto internacional.

A divisão fonográfica da Warner Communications possuía três selos: Warner, Elektra e Atlantic, que se comportavam ainda como gravadoras independentes. Pois, mesmo tendo sido vendidas, os donos dos selos permaneciam na liderança, com grandes participações nos lucros de suas marcas. A Atlantic Records tinha um catálogo independente, especializado em artistas de jazz, soul e R\&B, como Ray Charles, Roberta Flack e Aretha Franklin, e foi adquirida pela Warner em 1967. A vantagem de possuir um vasto catálogo musical era um "importante trunfo para a produção de coletâneas,

46 Na Philips, Midani também passou a empregar outra estratégia. Primeiro, separou a "nata” da MPB e cantores mais popularescos em dois selos: Philips e Polydor. E os artistas que vendiam 4 mil discos que permaneceram na Philips passaram a receber todas as atenções da gravadora, que realizava campanhas de marketing, peças publicitárias, investia mais em produção, tecnologia e divulgação, passando a vender 40, 50 mil cópias. Com isso, a gravadora tornou-se bastante lucrativa, aumentando sua participação de $7 \%$ a $8 \%$ para $18 \%, 19 \%$ do mercado. (MIDANI, 2009) 
compilações e mesmo para a consolidação no mercado de novos formatos". (VICENTE, 2002, p. 335) Assim, para aproveitar o catálogo da Atlantic, a WEA passou também a investir na cena black nacional, se tornando uma espécie de "ponto de convergência para muitos eventos relacionados com o movimento black, promovidos por DJs nos subúrbios do Rio e de São Paulo”. (MIDANI, 2009, p. 102) André Midani considerava que a Black Rio poderia ser o primeiro movimento musical inteiramente negro a produzir um tipo de música que não fosse o samba (BAHIANA, 2006, p. 306) e investiu muito em seus contratados, pensando em criar uma espécie de Motown brasileira. ${ }^{47} \mathrm{Na}$ época, diante do fim de movimentos como a Jovem Guarda, a Tropicália e a Bossa Nova, o soul poderia ocupar esse espaço na produção de uma música para um público jovem.

O segmento fonográfico da soul music já vinha sendo explorado no Brasil há alguns anos. De acordo com Sansone (2004, p. 171), o primeiro disco de soul lançado no Brasil de que se tem conhecimento trazia o título inglês What is soul?, lançado em 1967 pela CBD. O LP apresentava uma compilação de diversos cantores - Aretha Franklin, Percy Sledge, Joe Tex, The Capitols, Wilson Picket, Sam \& Dave etc. - e a capa exibia uma foto de jovens brancos dançando ao lado de uma descrição do que seria o soul. Tanto pela foto quanto pelo texto, percebia-se a estratégia da gravadora de desvincular a sonoridade de uma produção racializada, atrelada diretamente à cultura negra urbana norte-americana, ignorando a utilização corrente, nos EUA, da expressão black music. ${ }^{48}$ A proposta da gravadora, naquele momento, era apresentar o

47 Nirto, da SGP, fala a respeito do investimento na busca de novos talentos: "Aí alugaram para a gente um apartamento em Ipanema, na Visconde de Pirajá, e deram um gravadorzinho para registrar tudo o que tivesse em termos de black brasileiro". (ESSINGER, 2005, p. 36)

48 "Dia a dia surge uma novidade no mundo da música em todos os cantos do mundo. E cada inovação ganha sempre um nome pequenino, mas com a intenção de definir algo muito grande e elevado. Assim é o 'soul', a última inovação surgida no mundo da música e que consegue uma aceitação das maiores, principalmente pelo público jovem que, como sempre, é o primeiro a aceitar, adotar e beber o que vem com característica de novidade. As letras contêm mensagens de muito sentimento e ternura, embora o ritmo seja alegre e bem dentro da linha do que o jovem prefere e exige... É o que se dança e se canta em todas as boates ianques, em todas as 'caves' de Paris e do resto da Europa. E como o vento é que traz ligeiro as novidades musicais, num instante ele se fez presente no Brasil, onde aos poucos começa a infiltrar-se...”. (SANSONE, 2004, p. 171) 
soul como uma novidade popular da música jovem da época, moda em boates europeias, desarticulando essas produções de uma possível associação a questões de raça, especialmente a um discurso de afirmação de uma negritude - mesmo que a maioria dos cantores que figuravam nessa coletânea fossem negros.

No começo dos anos 1970, o soul ocupava lugar de destaque nos índices de vendagens de compactos simples no Brasil, como o do grupo Greaves, com o disco Take a Letter Maria (ATCO, 1970), o conjunto Sly \& The Family Stone (Thank You, Epic, 1970) e o compacto Yester me, Yester you, Yesterday (Tamla, 1970), de Stevie Wonder, que ficou entre os 20 mais vendidos no país, segundo o Instituto Brasileiro de Opinião Pública e Estatítisca (Ibope). (SCOVILLE, 2008, p. 36) Já o soul brasileiro de cantores como Tim Maia e Hyldon também era um gênero bastante consumido naquele momento. Dados do Nelson Oliveira Pesquisas de Mercado (Nopem), baseados em informações de lojistas do Rio e São Paulo, ${ }^{49}$ apontam que o segmento do soul, categorizado conjuntamente com rap e funk, de 1971 a 1977, manteve, anualmente, de 1 a 2 discos entre os 50 mais vendidos de cada ano. Ao analisar esses dados, Vicente (2009) constatou que, em 1971, Tim Maia, com o disco homônimo (Tim Maia, Philips), ficou em $26^{\circ}$ lugar, sendo citado mais a frente, em 1974, junto com Hyldon (Na rua, na chuva, na fazenda, Philips, $28^{\circ}$ lugar), que, no ano seguinte, ficou em $32^{\circ}$ lugar com Na sombra de uma árvore (Philips, 1975). Em 1976, Cassiano ficou em $25^{\circ}$ lugar (A Lua e eu, Philips) e Cláudia Telles (Fim de tarde, CBS) em 50 $0^{\circ}$ lançada pela CBS naquele momento como uma versão brasileira de Diana Ross. É importante lembrar que a Philips tinha um forte segmento de soul music por conta da atuação de André Midani, que manteve seu apoio à black music brasileira também na WEA.

O soul também foi bastante representativo no V Festival Internacional da Canção (FIC) de 1970, que expôs o gênero para uma maior audiência por

49 “A Nopem, Nelson Oliveira Pesquisas de Mercado, é uma empresa carioca criada em 1965 com o objetivo de atender exclusivamente à indústria fonográfica. Nelson Oliveira, seu fundador, trabalhara anteriormente no lbope e estruturou sua pesquisa de venda de discos a partir de informações de lojistas do eixo formado pelas cidades do Rio de Janeiro e São Paulo. As listagens não trazem quantidades de vendas, mas apenas a posição anual de cada álbum no ranking dos 50 mais vendidos". (VICENTE, 2006, p. 2) 
meio de novos cantores, como Tony Tornado, o conjunto Dom Salvador \& Abolição, o Trio Ternura e Erlon Chaves. As canções "BR-3", vencedora da etapa nacional do V FIC na voz de Tornado, e "Eu também quero mocotó" foram amplamente executadas nas rádios, o que ajudou na venda de seus respectivos compactos, potencializando o soul no mercado. E, de certa forma, o evento "serviu de campo de sondagem, que desta vez atuou a favor da indústria fonográfica, que buscava uma reformulação na produção musical” (SCOVILLE, 2008, p. 35), potencializando o segmento do soul. O FIC também funcionava como uma espécie de celeiro de novos sucessos para a programação musical e para a trilha das novelas da Rede Globo, uma das realizadoras do festival.

Outra gravadora que investiu no soul foi a Tapecar, que editou no país títulos da Motown e LPs de artistas da Tamla. A Tapecar era uma gravadora industrial e fábrica de cartuchos sonoros para carros e se transformou em selo musical no início da década de 1970, também lançando discos de samba e MPB ${ }^{50} \mathrm{O}$ segmento ainda envolveu outras grandes gravadoras do país, como a CBS, ou menores, como a Top Tape e a Continental, de acordo com Dias (2000, p. 76), e ainda a Phonogram, cujo gerente de produtos, Roberto Menescal afirmou na época: “[...] eu diria que a saída é o soul, porque o pessoal do black soul amanhã vai acabar fazendo black samba. Vai ser legal porque vai trazer uma nova maneira de ver o samba”. (BAHIANA, 2006, p. 306) Às gravadoras, de fato, não poderia ser creditado exclusivamente o sucesso do soul no Brasil. Mas, de fato, os executivos das companhias estiveram atentos ao fenômeno, inclusive desenvolvendo estratégias para dar mais visibilidade ao movimento e, por conseguinte, chamar a atenção da imprensa e do público para futuros lançamentos discográficos, como assume André Midani (2009, p. 103) em seu livro Música, ídolos e poder, após ir a um baile black no subúrbio carioca:

Nas semanas seguintes, chamei jornalistas cariocas e paulistas que eu conhecia, e organizei várias caravanas para Olaria. As

50 A empresa encerrou suas atividades em 1980, ao vender seu catálogo para a Som Livre. Na década de 1990, todo o seu acervo foi licenciado à Discos Copacabana, que posteriormente foi adquirida pela EMI. Desde 2011, o acervo da Tapecar vem sendo restaurado e digitalizado pelo selo Discobertas. 
reportagens começaram a aparecer no Rio e em São Paulo, criando uma controvérsia grande, a favor e contra os blacks, sua cultura e sua música, que muitos julgavam alienada, temendo que tais manifestações viessem a destruir a tradição secular dos morros. Para culminar, a revista Veja publicou em 1978 uma longa reportagem de seis a sete páginas, ampliando os debates e pondo fogo nesse confronto entre 'Velhas Guardas versus Jovens Guardas', que no final se resumia a 'samba versus soul', ou 'tradição versus evolução'. Pouca gente considerava que essas modalidades pudessem conviver. ${ }^{51}$

Outro célebre texto que descortinou os bastidores das ações empresariais da indústria fonográfica em torno do movimento foi redigido pela jornalista musical Ana Maria Bahiana e publicado em fevereiro de 1977 no Jornal da Música, que tinha grande circulação na época. No artigo "Enlatando Black Rio”, republicado em 2006, Bahiana abordava a suposta manipulação por parte das gravadoras do mercado black, reafirmando o movimento soul como mais uma criação da indústria cultural sem qualquer fundamento político e que poderia angariar altos ganhos para as gravadoras:

Um mercado de bom tamanho - de 10 a 20 mil consumidores certos -, com índice ótimo de homogeneidade e resposta a estímulos. Um mercado que podia, bem manipulado, ser o estopim de outro muito maior, Black São Paulo, Black Salvador [...]. (BAHIANA, 2006, p. 305)

Uma das estratégias empregadas com ampla lucratividade era o lançamento de coletâneas com os nomes das principais equipes ou dos DJs mais famosos, que poderiam fazer uma espécie de curadoria. Restrições de importação limitavam severamente a chegada ao mercado de discos brasileiro de selos norte-americanos independentes, como Motown e Stax, o que favorecia as majors com afiliadas brasileiras como a CBS e a Philips. Essa vantagem permitia que as multinacionais, ao lado de selos brasileiros regionais,

51 Midani se confunde porque, na verdade, a revista Veja publicou duas matérias abordando a Black Rio, sendo a primeira, com cinco páginas, em 1976 e a segunda, com apenas duas páginas, em 1978, esta um obituário sobre o falecimento do compositor Candeia. 
adquirissem os direitos para distribuir singles americanos independentes no país, lançando coletâneas localmente que rendiam altos lucros. No princípio, gravadoras menores, como a Continental, Top Tape e a Tapecar, lançaram as primeiras coletâneas com repertórios dos hits mais tocados por equipes famosas. (BAHIANA, 1980, p. 218) Sem perder tempo, os diretores de outras grandes gravadoras multinacionais com sede no Brasil logo se mobilizaram para também aproveitar a onda black no mercado do disco, empurrando selos domésticos para as margens. Por volta de 1977, além da Warner, todas as gravadoras brasileiras, incluindo a CBS, a Polygram e a Phonogram, antiga Philips, tinham em mãos uma série de projetos relativos à formação de uma cena black na música brasileira, e o movimento ganhou projeção nacional. (RAMOS, 2007, p. 65)

Assim, as músicas mais tocadas nos bailes poderiam ser adquiridas pelos participantes, ou novos lançamentos do catálogo das gravadoras passavam a ser tocados diretamente nos bailes, que tinham um alcance maior do que a rádio ou a TV naquele contexto. As coletâneas de hits funcionavam também como peças de divulgação de vários novos artistas da black music internacional em um mesmo produto, tornando-o bastante atrativo, especialmente em um momento de retração no consumo ocasionado pelo fim do milagre econômico. Mesmo diante da recessão, o mercado de aparelhos de reprodução sonora cresceu em $813 \%$ até o começo da década de 1980 (ORTIZ, 1999, p. 120), e as coletâneas colaboraram de forma decisiva para a ampliação do mercado fonográfico brasileiro, garantindo publicidade e alta lucratividade a um custo bem mais baixo. A gravadora repassava uma parte das vendagens para as equipes, que se tornaram cada vez maiores e mais rentáveis. Esse êxito também acompanhava o aumento da popularidade da música americana vendida no Brasil por intermédio das afiliadas locais. O poder econômico das multinacionais ainda garantiu uma maior distribuição de discos por todo o país, bem como a compra de espaços publicitários na TV, e o soul entrou até nas trilhas sonoras de novelas e de programas musicais nacionais.

Bahiana (2006) também documentou em um dossiê o investimento no soul realizado por outras gravadoras, como a Phonogram-Polygram, ainda bastante articulada ao mercado da MPB, que investia no soul brasileiro de 
Cassiano e Tim Maia, além de lançar o primeiro disco da União Black ${ }^{52}$ para concorrer com a Banda Black Rio da WEA, tendo à frente o cantor Gerson King Combo, que logo depois lançou seu primeiro disco solo, em 1977. Esses nomes deram forma à divisão interna desse segmento na gravadora, estratégia semelhante à da CBS, que desejava ocupar a faixa de mercado dominada pela música americana contratando o cantor e compositor Robson Jorge - que trabalhou com Tim Maia -, autor do sucesso "Fim de tarde", interpretado por outra contratada da gravadora, Cláudia Telles, trabalhada pela CBS para ser uma versão nacional da cantora Diana Ross. Ainda integravam o cast da gravadora a mineira Rosa Maria e o grupo Alma Brasileira, composto por integrantes da escola de samba carioca Mocidade Independente de Padre Miguel. Para dar o pontapé inicial no segmento soul, a CBS organizou a coletânea Brasoul, LP lançado simultaneamente no Brasil e nos EUA, representando a decisão da companhia de trabalhar com o segmento soul no mercado brasileiro e americano ao mesmo tempo. A Continental foi a última a penetrar no mercado black, contratando o cantor e compositor Dom Mita, que misturava samba e soul utilizando instrumentos como o surdo no lugar do contrabaixo e substituindo a guitarra pelo cavaquinho. Outros cantores de soul brasileiros também foram lançados, mas sem muito sucesso, como Miguel de Deus e Tony Bizarro.

A Som Livre, gravadora brasileira pertencente à Rede Globo, tinha um acordo com a Top Tape, que detinha os direitos de distribuição da gravadora Motown no Brasil. Assim, o repertório internacional das trilhas sonoras das novelas globais, a partir de 1971, passaram a apresentar uma quantidade imensa dos contratados da Motown, como Stevie Wonder, Michael Jackson, Gladys Knight \& The Pips. Muitas das canções incluídas nas trilhas rapidamente eram lançadas em compactos, que logo entravam para a lista dos mais vendidos. O programa Som Livre exportação, veiculado pela Rede Globo de 1970 a 1971, também ampliou a divulgação do soul no Brasil, consolidando

52 Segundo Essinger (2005, p. 38), a União Black era originalmente um grupo de samba do subúrbio: "Com o aval do produtor e integrante dos Fevers Pedrinho da Luz, Gerson então conseguiu roupas blacks para a rapaziada, ajudou na composição das músicas e o disco foi feito. A foto da capa, curiosamente, foi tirada com a banda posando nas ruínas do Astória, lá onde começara Mr. Funky Santos". 
a tendência no mercado de discos. Ocupando a lacuna deixada pelos extintos programas O fino da bossa, Jovem guarda e Divino, maravilhoso, da década de 1960, com recorrentes apresentações de músicos como Tim Maia e Tony Tornado, o programa Som Livre exportação era também resultado da parceria comercial com a Philips-Phonogram - maior gravadora do país, que tinha em seu cast todos os grandes nomes da MPB, menos Roberto Carlos -, que também tinha um acordo com a Rede Globo para a produção de todas as trilhas de telenovelas. (SCOVILLE, 2008) Responsável por altos índices de vendas, o soul tornou-se um segmento rentável e lucrativo, concretizando as expectativas dos críticos ao movimento, que denunciavam o caráter mercantilizado da Black Rio.

\section{A Banda Black Rio}

Com o sucesso dos bailes e a maior difusão de gêneros da black music norte-americana nas rádios brasileiras, artistas nacionais que cantavam soul music começaram a despontar e a gravar discos de grande sucesso. Mesmo antes desse êxito alavancado pelos bailes, a black music já influenciava o trabalho de muitos artistas brasileiros. Além dos já consagrados Tim Maia ${ }^{53}$ e Jorge Ben Jor, novos nomes como Hyldon e Cassiano, antigos parceiros de Tim Maia, angariaram excelentes resultados para a indústria fonográfica. Tony Tornado, Bebeto e Gerson King Combo, diferentemente dos outros cantores de soul brasileiros, ganharam impulso em suas carreiras ao articularem diretamente suas imagens aos bailes black, realizando grandes shows a partir de contratos com as equipes de som.

A boa repercussão do segmento incentivou a WEA, Warner Music do Brasil, que, em 1977, incumbiu ao músico Oberdan Magalhães, a pedido da matriz norte-americana, a criação de uma banda que mesclasse a soul music com a música negra brasileira mais conhecida no exterior: o samba. "A Warner está animadíssima, tem toda uma transação em cima de música negra,

53 Sobre a importância do soulman Tim Maia, Ramos (2007, p. 68) comenta: “Os Lp(s) lançados por ele ao longo dos anos 70 são bases fundamentais da música pop que se desenvolveu no Brasil nas décadas seguintes e estão entre os exemplos mais bem acabados de nossa música em termos de produção de discos dentro de um estúdio". 
sabe, eles estão formando uma banda, o Oberdan e esse pessoal, eles estão recebendo um fixo para ensaiar todo dia e criar um som black brasileiro", comentou Marinaldo Guimarães, na época, empresário do cantor Luís Melodia. (BAHIANA, 2006, p. 303) Inicialmente chamada de Black Rio Band, contava com Oberdan no sax e outros músicos, como Barrosinho no trompete, Luís Carlos Batera, Cristóvão Bastos ao piano, Claudinho Stevenson na guitarra, Lúcio do Trombone e Jamil Joanes no baixo, músicos experientes, mas "[...] do subúrbio, marginalizados no mercado da MPB fina". (ESSINGER, 2005, p. 37) Com produção artística de Dom Filó, na época também contratado da WEA, surgia, assim, a Banda Black Rio, após três meses de ensaios. ${ }^{54}$

O som produzido pela banda era uma grande fusão entre a black music internacional, o samba - especialmente o samba de gafieira - e a improvisação "jazzística", a partir de uma base instrumental que executava arranjos originais e demonstrava a competência dos músicos integrantes do grupo. Oberdan demonstrava, com esse trabalho, as influências que recebera do universo do samba e o do jazz. Além de sobrinho do sambista Mano Décio da Viola, Oberdam era primo de Silas de Oliveira, um dos fundadores da escola de samba carioca Império Serrano e compositor do consagrado samba "Aquarela do Brasil”. E o músico começou a estudar música com Paulo Moura, um dos mestres do saxofone brasileiro, quando tinha 15 anos. (RAMOS, 2007, p. 70) Diante do convite da Warner, o músico convidou alguns membros do grupo Impacto 8 - formado em 1967, que também deu origem à Banda Abolição, liderada pelo pianista Dom Salvador - e também dos conjuntos Senzala e Cry Babies. Nascia assim, ao final do ano 1976, a formação original da Black Rio.

54 "A gravação que o Mazzola produziu com a Banda Black Rio foi um momento muito importante na vida musical do país, pois o grupo reunia os mais importantes músicos black do Rio de Janeiro. Oberdan, líder da banda, desenvolveu arranjos surpreendentemente ousados e modernos, que fizeram com que o álbum Maria Fumaça se tornasse, até hoje, uma referência entre os músicos brasileiros devido ao seu conceito inovador e, sobretudo, à influência que exerceu sobre os destinos musicais do funk brasileiro, que estava nascendo, inicialmente pela influência musical do Jorge Ben Jor, do Tim Maia e, naquele momento, dessa banda. O negro podia se expressar de muitas maneiras - sem ficar unicamente confinado ao samba e, no entanto, sem o renegar". (MIDANI, 2009, p. 102) 
No começo, a banda não atendeu imediatamente às expectativas da indústria fonográfica. Sua primeira apresentação-teste, acompanhando o cantor Luís Melodia em uma performance ao vivo em um show no MAM, Zona Sul do Rio, e depois durante um baile no Clube Olaria, no subúrbio, não cativaram o público, particularmente por conta da ênfase em composições instrumentais, que não dialogavam diretamente com os fãs da black music naquele momento, segundo Ramos (2007). Mas André Midani e a WEA já consideravam essa reação, visto que a proposta da banda era fazer música de "alto nível”, comparável ao trabalho de músicos como Hermeto Pascoal e Egberto Gismonti: "Ela é instrumental, mas ligada ao som das gafieiras, aos bailes populares, ao Astor e Seu Conjunto, que foi a formação desses músicos”. (BAHIANA, 2006, p. 309) Oberdan Magalhães também explicou após o espetáculo: "O som da banda não é propriamente feito para dançar, nós estamos a fim de fazer um som forte, uma música alegre”. (BAHIANA, 2006, p. 308) Uma solução para tornar os shows da Banda Black Rio mais populares foi a contratação dos cantores Sandra de Sá e Carlos Dafé - que depois seria contratado pela WEA em carreira solo - para acompanhar o grupo nas apresentações seguintes. O primeiro disco, Maria Fumaça (1977, Warner), era inteiramente instrumental e trazia clássicos da música brasileira em versões repaginadas, como "Na Baixa do Sapateiro", de Ary Barroso, e "Casa Forte", de Edu Lobo, em uma proposta clara de renovação e mistura de sonoridades e gêneros. Sobre o disco, Oberdan comentou: "Essas músicas mostram todo sentido da alquimia e da transformação que estamos propondo, porque a música popular brasileira precisa ser renovada, remexida, com todos os sons, sem preconceitos". (BAHIANA, 2006, p. 310)

A crítica especializada elogiou o trabalho, apesar do disco não ter obtido grandes índices de vendagem. Não tanto quanto discos de hits dos bailes lançados por DJs e equipes de som de gravadoras independentes, como a Top Tape e a Tapecar. Mesmo assim, a Banda Black Rio conseguiu ter suas músicas circulando em nível nacional, em especial por conta da participação na trilha sonora de uma novela global - a faixa "Maria Fumaça" foi incluída na trilha da novela Locomotivas, em 1977. No ano seguinte, a banda acompanhou Caetano Veloso na turnê Bicho Baile Show, em maio de 1977, com o repertório de canções do LP Bicho (Philips, 1977). O show, que tinha um mote 
mais dançante e pop, foi levado até para a quadra da escola de samba Beija Flor, em Nilópolis, a fim de atingir um público mais popular. Seu registro ao vivo foi lançado em CD apenas décadas depois, mas o show representou um momento de grande projeção para a banda. ${ }^{55}$ Em 1978, com menos canções instrumentais e um apelo mais comercial, o grupo lançou o segundo disco, Gafieira universal, pela RCA-BMG.

A mudança para a RCA trouxe alterações concretas na proposta sonora inicial do grupo, a fim de popularizar mais o trabalho, e a gravadora impôs a inserção de vocais e a produção de gravações com uma roupagem mais pop, o que não foi aceito por alguns integrantes, que abandonaram o grupo. O terceiro LP, Saci Pererê (RCA Victor, 1980), foi lançado já no declínio da cena da Black Rio, mas a banda continuou fazendo shows até o falecimento de Oberdan, em um acidente de carro em 1984.

Ao lado da Banda Black Rio, os grupos Dom Salvador \& Abolição e União Black inspiraram o surgimento, no subúrbio carioca, de alguns conjuntos oriundos de festas e gafieiras, que criaram um circuito paralelo, mas convergente à cena dos bailes black. Esses conjuntos eram também influenciados por grupos de funk norte-americanos, como Earth Wind and Fire e KC \& The Sunshine Band, e ainda pelas orquestras de gafieira tradicionais. Ainda hoje em atividade, conjuntos de baile como Copa 7, Os Devaneios e a Banda Brasil Show executavam canções de sucesso e também composições próprias, todas voltadas para a execução de passos de dança no salão, em que os arranjos de metais eram articulados a teclados, baixos e guitarras, que modularam uma sonoridade até hoje identificada com a prática do samba de gafieira moderno, mesclando samba e black music.

\section{MPB+soul}

E a soul music, que chegava ao Brasil através dos bailes, começava efetivamente a ocupar a significativa fatia da música estrangeira nas gravadoras

55 Sobre esse show, Caetano Veloso comenta em artigo publicado na Revista Música de 1977: “[...] o show é bem uma apresentação de banda. Eu estou presente, a minha transação se dá por inteiro. É bacana, mas é bem mais uma apresentação de banda. Eu fiz questão que fosse assim, porque eles são músicos muito bons”. (RAMOS, 2007, p. 71) 
nacionais, se fazendo também mais presentes no universo composicional da MPB que, naquele momento, já havia absorvido a ideologia tropicalista baseada na incorporação de elementos da cultura de massa. A sigla MPB foi um rótulo fonográfico que incorporava vários gêneros e estilos musicais urbanos desenvolvidos a partir de 1965 e simbolizava especialmente a música popular urbana do período pós-tropicalista. A MPB acabou por forjar uma identidade estética e ideológica para setores médios dos principais centros urbanos, especialmente para uma pequena parcela universitária ou para grupos de intelectuais e artistas, e correspondia a um imaginário coletivo de uma resistência política e cultural. O termo guarda-chuva englobava a moderna produção musical massiva urbana que emergiu a partir da Bossa Nova (NAPOLITANO, 2002b), reunindo uma série de convenções culturais, movimentos e estilos que atualizaram a tradição do samba, exercendo novos cânones e padrões de valor e autenticidade. Sob o aval da indústria fonográfica do período, a MPB era caracterizada por uma produção musical que reunia apuro estético e pesquisa de tradições nacionais populares, com o objetivo de criar composições “de qualidade”, mas que, especialmente após a Tropicália, passou a dialogar com influências massivas do pop internacional.

A popularidade no país de nomes como Aretha Franklin, James Brown e Stevie Wonder aumentava e também exercia grande influência sobre muitos artistas brasileiros. Compositores, músicos e arranjadores começaram a inserir mais veemente em suas canções elementos anteriormente considerados antagônicos, renovando suas estratégias midiáticas e popularizando seus trabalhos em consonância com novas tendências de consumo. Essa hibridização não era uma prática nova e correspondia a uma nova etapa da incorporação de gêneros estrangeiros à música brasileira, como ocorreu com o jazz (com o samba-jazz e a bossa nova), depois o rock (com a Tropicália e a Jovem guarda), atualizada naquele momento pelo contato com a black music norte-americana.

De certa forma, já em 1969 a tendência da introdução do soul na MPB começava a se confirmar, especialmente com o êxito da gravação por Roberto Carlos do soul "Não vou ficar". Um ano depois, Elis Regina gravou "These are the songs" (Em pleno verão, 1970, Philips), um dueto com Tim Maia, compositor da canção e também autor do sucesso de Roberto Carlos. Foi o 
pontapé inicial para uma carreira de sucesso e para a consolidação do soul no cenário musical brasileiro. Tim Maia, que já havia estourando nas rádios no final do ano anterior com "Primavera", lançado em um compacto simples, gravou seu primeiro disco, Tim Maia (Polydor), em junho de 1970. Acompanhado pelos Diagonais, grupo liderado pelo guitarrista e compositor Cassiano e acompanhado pelos músicos Hyldon, Camarão e Amaro, Tim Maia se tornou o principal representante do núcleo do soul brasileiro, ao lado de Jorge Ben. Mas as características estilísticas dos dois músicos diferenciavam-se, no sentido de que Tim Maia se voltava mais para uma produção ligada à black music norte-americana original, enquanto Jorge Ben se interessava por hibridizar o samba de diversas maneiras.

Alguns compositores de MPB, como Marcos Valle, de origem bossa-novista, e Ivan Lins, aderiram ao soul, tal como António Adolfo e Tibério Gaspar, dupla de compositores de procedência jazzística que encontraram no soul o caminho para o sucesso, vencendo o $5^{\circ}$ FIC com "BR-3", interpretada por Tony Tornado em 1970. O $5^{\circ}$ FIC, em especial, promoveu o então novo segmento do mercado, potencializando o soul na indústria fonográfica. No festival, outras composições também obtiveram destaque como "O amor é o meu país”, de Ivan Lins, e “Abolição 1860-1980”, do conjunto Dom Salvador e Abolição. A composição "Eu também quero mocotó”, de Jorge Ben Jor, foi defendida pelo maestro e arranjador Erlon Chaves, acompanhado pela Banda Veneno, e ficou em sexto lugar. A canção, ao lado de "BR-3", foi uma das favoritas do festival, amplamente executada nas estações de rádio, motivando grandes vendas de seus respectivos compactos.

\section{Brazilian disco music}

Para Bahiana (1980, p. 48), em meados dos anos 1970, duas linhas de produção emergiram nos EUA: uma se manteve mais fiel aos padrões de gosto das populações jovens e negras - o soul repaginado e transformado em funky music-; e a outra aproveitava apenas os padrões rítmicos e o pulso dançante em formas mais diluídas e comerciais para um público mais amplo - a discothèque. O crítico musical Tárik de Souza (1976, p. 10) considerava a disco uma "espécie de filial pilantragem do soul", em referência ao movimento 
encabeçado por Wilson Simonal nos anos 1960, baseado em canções mais comerciais, divertidas e dançantes que seguiam fórmulas pré-determinadas. Em torno de 1975, a moda mundial da disco music chegou ao Brasil através de nomes como Donna Summer, Chic, KC \& The Sunshine Band, Gloria Gaynor, entre outros, incluindo artistas originalmente identificados com o soul e funk que voltavam-se para a nova moda. De fato, como confirmam os dados da Associação Brasileira dos Produtores de Discos, em 1978, dos 30 álbuns mais vendidos em São Paulo e Rio de Janeiro, 16 eram LPs de discoteca. (RODRIGUES, 2003, p. 10)

Criada nos EUA e voltada para as pistas dos clubs, a disco music mesclava ingredientes do rock e do soul, mas sem sombra de pregação racial. A gravação "Soul Makossa”, do saxofonista camaronense Manu Dibango, lançada em 1972, é considerada uma das primeiras gravações do gênero e tornou-se um hit mundial. Apesar do sucesso comercial, a música disco foi frequentemente denegrida por alguns críticos por conta de sua influência pasteurizante sobre a música popular, a partir da utilização de baterias eletrônicas, teclados e sintetizadores (SHUKER, 1999, p. 99), em canções dançantes e melodiosas que falavam de amor, exaltavam a dança e a vida noturna. Para outros, no entanto, essa forma musical, apesar de considerada superficial e alienante, expressava, através da dança, uma vitalidade libertadora, inovadora e sensual. A disco emergiu a partir de uma "subcultura", no início dos anos de 1970, baseada em boates frequentadas por grupos negros e gays, e o gênero musical, no auge do sucesso, acabou por dominar a música pop por alguns breves anos, restaurando o hábito da dança como um "imperativo pop". (SHUKER, 1999, p. 99) As gravações de disco music continham, basicamente, pouca ou nenhuma letra, baseando-se em ritmos marcados e de batidas repetitivas (DOURADO, 2004, p. 109), e acabaram por influenciar toda a música pop mundial, dando origem à dance music e aos vários gêneros da música eletrônica. $\mathrm{O}$ Brasil também teve sua "diva disco", a cantora paulistana Lady Zu, cujo estilo era inspirado na cantora norte-americana Donna Summer. Lady Zu estourou com a música "A noite vai chegar" (Phonogram), carro-chefe do compacto de 1977, que vendeu um milhão de cópias, e foi incluída na trilha sonora da novela Sem lenço, sem documento, da Rede Globo. O sucesso lhe valeu o título de "Rainha da Discoteca Brasileira" e possibilitou a gravação do seu segundo LP, Fêmea 
brasileira (Phonogram), em 1979. Incorporando a moda das discotecas da época, os arranjos do LP fundiam a fórmula da disco music com gêneros nacionais, como o baião e o samba. Da moda musical disco, também participou o produtor e tecladista Lincoln Olivetti, que gravou com Robson Jorge a música "Aleluia" (Robson Jorge e Lincoln Olivetti, Som Livre, 1982), um grande sucesso nas rádios. Se, por um lado, Olivetti desfrutava de grande sucesso comercial nessa época, conhecido como "o mago do pop" por renovar a carreira de vários artistas da MPB, por outro, atraiu críticas que o responsabilizavam pela "pasteurização" do gênero nos anos 1980. Mentor da sonoridade funk-pop de "Realce", de Gilberto Gil (Realce, WEA, 1979), também foi um dos produtores de Salve simpatia (Som Livre, 1979), disco que marcou uma nova fase para a carreira de Jorge Ben Jor, de orientação mais voltada para as pistas de dança, com gravações densamente marcadas pela presença de sintetizadores, criando as bases de uma espécie de "disco-samba".

Os diferentes processos na indústria fonográfica mundial dos anos 1970, como a segmentação e massificação do mercado, abriram espaço para a oferta de uma produção musical mais pop, diante da internacionalização cultural e da evolução das novas tecnologias de gravação. Como pontua Vicente (2002), a maior racionalização e especialização das atividades da indústria, obtida por meio de uma divisão do trabalho mais complexa e de uma sofisticação das técnicas de marketing e de produção, ao mesmo tempo em que levava a uma maior padronização dos segmentos predominantes no mercado, "[...] deu voz e identidade a segmentos sociais antes absolutamente ignorados no contexto da mídia nacional”. (VICENTE, 2002, p. 199) 